\title{
Monetary Expansion and Federal Open Market Committee Operating Strategy in 1971
}

\author{
by ALBERT E. BURGER and NEIL A. STEVENS
}

HE PRIMARY policy objective of the Federal Reserve System in 1971 was to continue progress toward expansion of real output and employment coupled with a slowing in inflation. The major policy instrument used in pursuit of this objective was open market operations, which are determined by the Federal Open Market Committee (FOMC). ${ }^{1}$

Expansionary policy actions taken in 1970 had laid the foundation for economic recovery in 1971. The money stock had increased at a 5.4 percent rate in 1970 compared to a 3.2 percent rate in 1969 . Longand short-term interest rates had declined markedly from peaks earlier in 1970. By the end of 1970, some small improvements toward the reduction of inflation could be noted, and further improvements in 1971 were anticipated. However, with unemployment at 6 percent and utilization of plant facilities at relatively low levels, unemployed resources remained a primary policy consideration.

Policy objectives of the Committee at the first three meetings were stated as follows:"

. . . to foster financial conditions conductive to the resumption of sustainable economic growth, while encovraging an orderly reduction in the rate of inflation and the attainment of reasonable equilib. rium in the country's balance of payments.

Other policy instruments of the Federal Reserve System, such as reserve requirements and Regulation $Q$ ceiling rates, were not altered in 1971. The discount rate was changed six times, lowered three times in January and February, raised in July, and then lowered two more times by the end of 1971. These changes, however, primarily represented attempts to keep the discount rate in line with prevailing market rates.

Unless specifically footnoted, all quotes in this article come from the "Record of Policy Actions" of the Federal Open Market Committee, publsshed in the Federal Reserve Bulletin.
The FOMC members were also concerned about large outflows of short-term capital that occurred during 1971. At the April meeting and continuing through the July meeting, a new clause was added to the policy consensus stating that the Committee desired to moderate these outflows. The policy consensus was further modified at the August meeting to take account of the President's New Economic Program. A clause was added stating the intention of the Committee to "foster financial conditions consistent with the aims" of the new program.

In accordance with the objective of promoting economic expansion without renewed inflation, the Committee desired throughout most of 1971 both relatively low interest rates and moderate growth of monetary aggregates. These intermediate objectives were to be achieved by setting forth specified ranges for measures of money market conditions - money market interest rates and net borrowed or free reserves - to be achieved by the Desk during the interval between each Committee meeting. ${ }^{3}$

As the year progressed, conflicting views on the relative importance that should be assigned to interest rates and monetary aggregates became evident. For example, at the May 11 FOMC meeting some members expressed concern "that expansion in $M_{1}$ [currency plus demand deposits held by the nonbank. public] at the first-quarter pace for an extended period would be inconsistent with an orderly reduction in the rate of inflation." Moderation of monetary growth would have required that the Desk be instructed to follow a less expansionary open market policy, which in the near term, most likely would

3 For a discussion of this type of operating strategy see page 13 . 
have lead to higher interest rates. Other members expressed the view that "sharp increases in long-term rates at this juncture might have adverse consequences for spending . . . and might thus pose a threat to the economic recovery under way." These members were reluctant to accept a more restrictive open market stance.

Later in the year an opposite type of conflict developed when the money stock had ceased to expand and interest rates had fallen. At the November meeting "[t]he view was expressed that it would be particularly unfortunate in this climate for the recent weak performance of the monetary aggregates to persist for long, since the lack of significant growth in the aggregates could become an important independent source of uncertainty. At the same time, some members cautioned against unduly aggressive action to stimulate monetary expansion."

An article in the Federal Reserve Bulletin discussed the possibility that such conflicts could develop:

These desires may sometimes turn out to be in conflict; for example, monetary aggregates as a group may be rising more rapidly than desirable while credit conditions may be tightening more than desirable. Meeting one desire by holding back on the provision of reserves in order to restrain growth in bank credik and money would tend, at least temporarily, to thwart the other desire by leading to ever more tightening of credit conditions. Under such circumstances, the Account Manager would have to adjust his operations - thereby affecting dayto-day money market conditions $-m$ in line with the sense of priority among operating objectives given by the FOMC.t

Throughout most of 1971, the Committee sought to resolve this problem by cautiously adjasting market conditions in seeking desired rates of monetary expansion.

This article is primarily concerned with an analysis of problems inherent in the operating strategy used by the FOMC. The following definitions are used: policty refers to the ultimate objectives of FOMC actions - total spending, output, employment, prices, and the balance of payments; intermediate objectives are desired movements in monetary aggregates and interest rates to achieve the Committee's ultimate objectives; operating strategy refers to the specific instructions given to the Desk as a means of achieving desired movements in the intermediate objectives.

The supplement at the and of this article reviews in greater detail the FOMC decisions in 1971 as pre-

"Monetary Aggregates and Money Market Conditions in Open Market Policy," Federal Reserve Bulletin (Febrwary 1971), p. 95 . sented in the "Record of Policy Actions." The membership, procedures, and terms used in connection with the FOMC are discussed in the section entitled "The Federal Open Market Committee in 1971" on page 13.

\section{Implementing Policy With a Money Market Conditions Strategy}

The operating strategy of the Desk remained essentially the same during 1971 as it had been in past years. This strategy, as described by Governor Andrew F. Brimmer, was as follows:

They [the views of the members of the FOMC] would also probably contan enough common elements relating to operating lactics to add up to a pattern of behavior which can be described as the pursuit of a money market strategy in the conduct of open market operations. Basic to this strategy is the focus on a configuration of money maket conditions as operating guides for the Manager of the SOMA [System Open Market Account]. While the specific money market varables have varied over time, they lave typically included: (1) member bank borrowings from the Federal Reserve Banks; (2) net tree reserves; (3) the Federal funds rate; and (4) the 3-month Treasury bill rate. These money market variables are to be used by the Manager to influence the belavior of a variety of intermediate financinl variables, which may include: (1) the general structure of nominal interest rates; (2) monetary on credit aggregates (such as the money supply - broadly or narrowly defined, member bank credit, deposits of ronbank financal institutions, or similar quantitative measures); and (3) the general enviroment of credit and banking market as reflected in expectations, and the demand for and supply of total credit in the economy. . . .

In other words, though reserve absorption or supplying operations in the maket, the Manager of the SOMA attempts to bring about or maintain a desimble set of money market conditions (e.g., raising or lowering the 3-month Treasury bill yield or rates on Federal funds) with the expectation that the intemediate monetary variables (e.g., bank credit or money supply) will contrat or expand at a rate consistent with the requirements of economic stabilixation. For each FOMC meeting, the staff prepares an analysis of the relationships likely to preval among money market conditions, interest rates, and the monetary aggregates over a coming period, indicating the growth rates in various aggregates expected to be associated with each of several described kinds of money market conditions. 5

The operating clause of the directive during 1971 placed varying emphasis on the intermediate objec-

"Andrew F. Brimmer, "The political Economy of Money: Evolution and Impact of Monetarism in the Federal Reserve System" (Paper delivered at the Fighty-fourth Ammal Meeting of the American Economic Association, New Orleans, Louisiana, December 27,1971 ), pp. 15-16, 17 . 


\section{The Federal Open Market Committee in 1971}

The trederd Opien Market Committee conkists: of the seven menbers of the Iederal Reserve board of

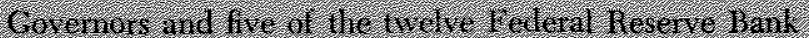

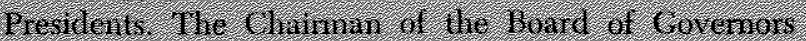
is ilso, It tradition Chimanin of the Committes. The

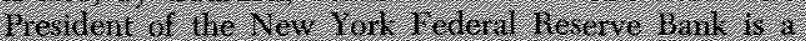
permanent veting nenber of the Commities and is:

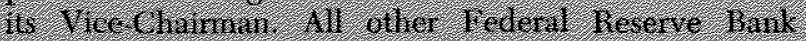
Prestidents attend the meetimss and present their view, bit totes miay be case by only loum of these Presidents, whi serve as voling members for me vent terms on a ritilion basis:

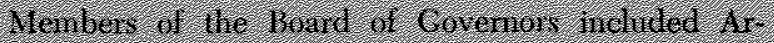

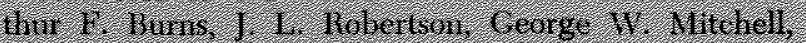

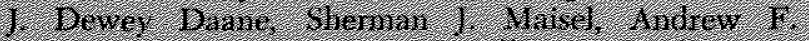

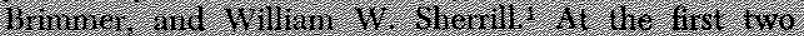

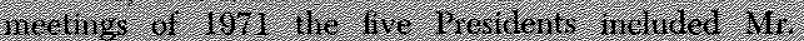

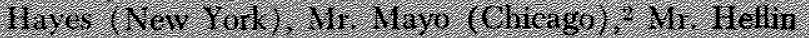

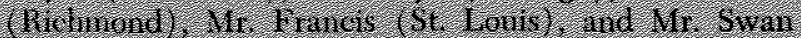
(San Tiancisco) Begrining with the Mard meeting:

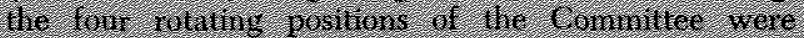
fllled by the following new nembers. Mr. Monsis

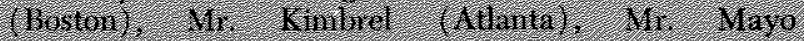

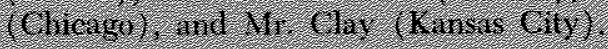

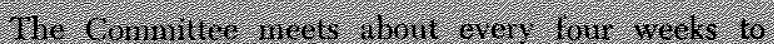

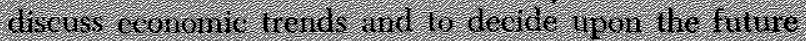
course if apen mathet operitions. At theso neetings.

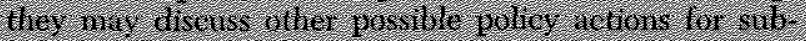

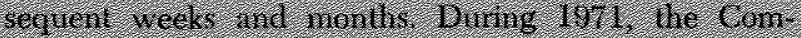
mittee net thimeon timer. At eact meeting a direce tive was istied with tated the ullimate goals of the Committce and provided general guidelines as to how the Manager of the Systeri Open Markel Revaint' at

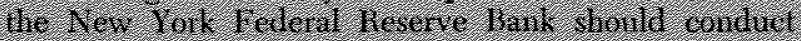
oper narkel operations to achiere these goals. The first pargeraph at tarth directie gave a short review of economie dith consithed and lie genemal ect.

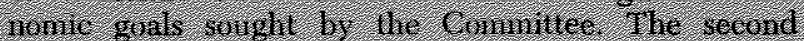
paragruph gate uperating instuietions to the Account

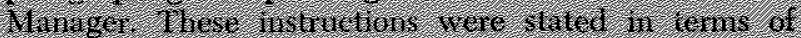
hiney and lougt tem gredit mintet conditoms gethth rates of monetary and etedil sggegates, and any spe: chal Iactors to be taken inte aceonnt, such as Treasury. fimancing uperations:

The tections on hie exict tinitig and amount of diaty bitying and telling operations of secanties in filtilling the Committees dinedtre are the responst: bihty of the Alecoint Manager at he Thating Degk of

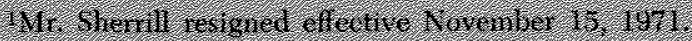

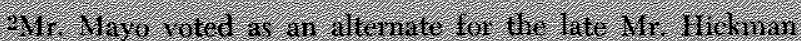
(Cleveland at ihe laniary and Felinar nectings:

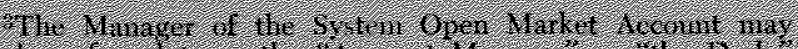

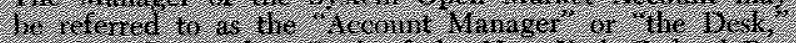
aneanity the Thuling Ded of the New Mork feterd he: serve liank: the New York Bank Each norining he and his stall devile on a program for upen namket operations to be

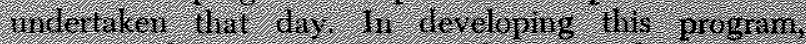
noney and credit ranket cunditions and argeregate

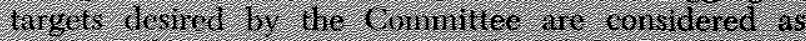
wetl as onlier lactoss which nay be of concern at that fine ted homing the Accoint Minager places a coifference call to stall member of the board of Cov. ermons and ane vatimg Dresident to vive infommation

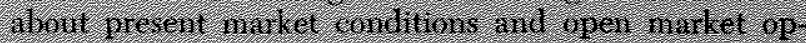
erations whith he pruposes to erecute that day. Other nembers of the Committee are inforned of the daily pingrinl by kita siminary:

A summan of the Commilteek neetings are pre.

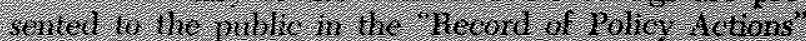

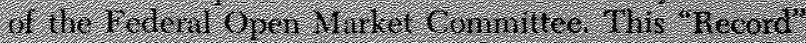
is retersed ahmt 90 dats after eath meetring and is publated in the leteral Reserte Bullems as well as

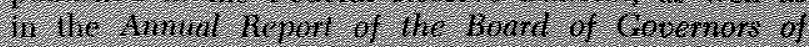

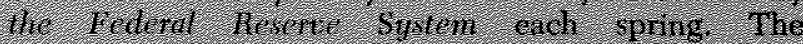

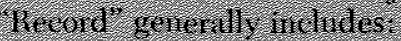

1) a. simmary of current ecrnomic echiditions, sich as prices, empluynent and the trend of the compoients of sgeregate demand: alsos. staft projections

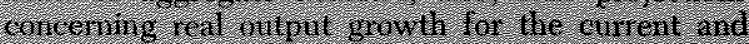
following tuarter (s) ive isually discissed:

2) a discassion of the U.S. bidance if paymients int diving internatimal finatictal developments;

3). a disenssion of interest rate movenients:

4) i discussion no the nowernents of menetary aggre: gates sth as $M_{1}$, and $M_{2}$, and the milusted credit proxyt Also meluelet ture comments concening

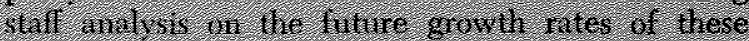

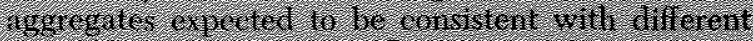

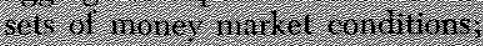

5) a distrission of spir namket operations stice the list inceting:

6) t teneral statement of the views af the nienbers of

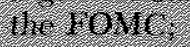

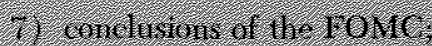

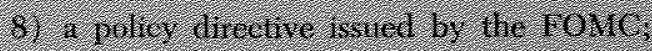

91. 1 list of lie voling position of mevilers and any Uis (nitinc cominents:

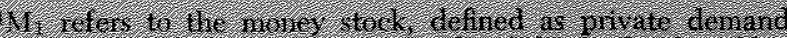

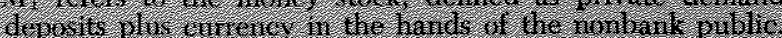

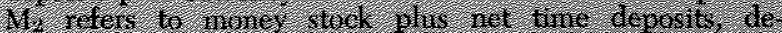

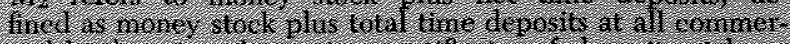

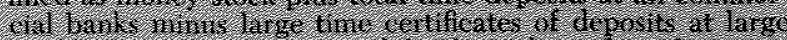

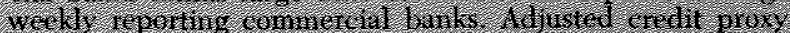

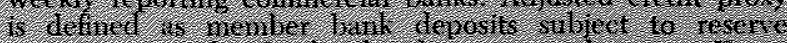

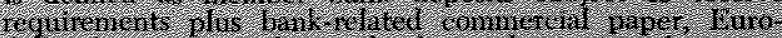

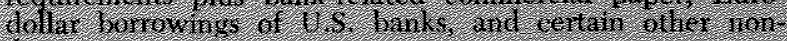

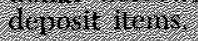


tives of monetary aggregates and interest rates. The policy directive issued at the first FOMC meeting in 1971 placed equal emphasis on credit market conditions and monetary aggregates.

To implement this policy, the Committee seeks to promote accommodative conditions in credit markets and moderate expansion in monetary and credit aggregates. System open market operations until the next meeting of the Committee shall be conducted with a view to maintaining bank reserves and money market conditions consistent with those objectives, taking account of the forthcoming Treasury financing.

At the next three meetings, howeves, wording of the directive was changed to place primary emphasis on money market conditions and long-term interest rates. For example, the February directive read:

. . System open market operations until the next meeting of the Committee shall be conducted with a view to maintaining prevailing money market conditions while accommodating additional downward movements in long-term rates. ...

Aggregates were relegated to the proviso clause which specified that money market conditions were to "promptly be eased somewhat further if it appears that the monetary aggregates are falling short of the growth path desired." At the March and April meetings, the proviso clause was modified to specify that money market conditions should be modified if it appeared that the monetary and credit aggregates were deviating significantly from the growth paths expected.

At the May 11 meeting the language of the direc. tive was shifted to place greater emphasis on growth of monetary and credit aggregates. Other objectives were also specified, including "taking account of the current Treasury financing, developments in capital markets, and uncertainties in foreign exchange markets."

The May directive specifed that, initially, money market conditions should be mantained at those currently prevailing. Thereafter, money market conditions were to be consistent with the objectives stated, including moderating growth in monetary and credit aggregates. At the remaining FOMC meetings in 1971, the language of the directives gave primary emphasis to monetary and credit aggregates. In addition, at several meetings it was noted that capital market developments should be taken into account as well as Treasury financings.

Growth rates of monetary aggregates were not the sole concern of the FOMC in 1971. However, at every meeting the aggregates were discussed and at most meetings some members of the FOMC expressed concern about their current and projected growth rates. At each meeting growth rates of the aggregates expected to be consistent with given money market conditions were presented to the Committee. To the extent that the Committee was interested in growth of the aggregates, these projections probably influenced the decisions of the FOMC members on money market conditions the Desk was instructed to maintain.

\section{Projecting the Growth of Money}

During the first half of 1971 projected growth rates for money that were expected to result from the adopted set of money market conditions were substantially below actual growth rates of money. On the other hand, during the second half of the year, projections, again based on the assumption of adopted money market conditions, were substantially above actual growth rates.

At the first three meetings of 1971 money was expected to grow at an anmual rate of about 6 to 7.5 percent during the first quarter. The actual rate was 9.4 percent. In the second quarter, estimates for the growth of money consistent with the adopted money market strategy ranged from about 8 to 9 percent at the April and May meetings. At the May meeting it was expected that "a sharp firming of money market conditions would be required to slow expansion in $M_{1}$ sufficiently during the rest of the second quarter to achieve a substantial moderation of growth over the quarter as a whole." Table I shows that there was some firming of money market conditions in May and June; however, money grew at an 11 percent rate over the second quarter.

The FOMC desired a more rapid growth in money over the frst part of 1971 than had occurred in the fourth quarter of 1970 . However, the rapid increase in money that occurred over the first half of the year clearly exceeded that expected to accompany the money market conditions adopted by the Committee. As early as the March 9 meeting, when a 7 percent monetary growth rate was projected for the first quarter, the FOMC decided that:

... money market rates were to be increased somewhat if the aggregates were rising considerably faster than expected. . .

Following the procedure used by the staff analysis for the FOMC, quarterly growth rates are calculated on the basis of the daily average level in the last month of the quarter relam tive to that in the last month of the preceding quarter. 


r
rafle

At the April 6 meeting, when the first quarter growth rate of money was estimated at 8 percent, the FOMC stated:

.. it would like to see more moderate expansion in the monetary aggregates in the second quarter than had occurred in the first.

From the March 9 meeting to the August 24 meeting, the Policy Record stated, in general, that open market operations were initially aimed at maintaining prevailing money market conditions, and then aimed at achieving slightly or somewhat firmer money market conditions as incoming data indicated the monetary aggregates were expanding significantly faster than expected.

During this period only gradual tightening of money market conditions was permitted. For example, in the period prior to the April 6 meeting:

... efforts were made during the period to counter repetitive tendencies toward undue firmness that arose from market factors affecting reserves.

Also in the period immediately following the May 11 meeting:

System open market operations had been directed at maintaining prevailing money market conditions ... in light of the Treasury financing then in process and the sensitive state of conditions in capital markets.

In late June the growth of money for the third quarter, with prevailing money market conditions, was projected to be at a slightly slower rate than the second quarter, and at about 9 percent with some firming in money market conditions. At the July 27 meeting projections were revised downward slightly to about an 8 to 9 percent rate with some further firming of money market conditions. The actual annual growth rate for money over the third quarter was 3.8 percent.

At the September 21 meeting it was projected that if prevailing money market conditions were maintained, growth in $M_{1}$ would be slower in the fourth quarter than in the third quarter. At the October meeting growth of $\mathrm{M}_{1}$ was projected to be about the same rate in the fourth quarter as the third quarter, assuming prevailing money market conditions. Money market conditions in fact eased, yet the actual growth rate for the fourth quarter was 1.1 percent.

\section{Inconsistency of Money Market Conditions and Desined Crowth of Money}

Although money market conditions approved at each meeting of the FOMC as operating instructions for the Desk may have been consistent with the members' intermediate objectives for market interest rates, these conditions were not consistent with the growth rates of money expected by the members. The growth trend of money accelerated at an extremely rapid rate over the first seven months of 1971 and then decelerated at an equally rapid rate in the latter part of the year.

Periodically some members of the FOMC expressed concern about the growth paths of the monetary aggregates that were resulting from the money market operating strategy. For example, Mr. Kimbrel dissented at the April meeting because he "believed that higher short-term interest rates would be desirable mainly to hold growth in the monetary and credit aggregates to a moderate pace in order to avoid a rekindling of inflationary expectations." At the May meeting "[t]he view was widely held among members that expansion in $M_{1}$ at the first-quarter pace for an extended period would be inconsistent with an orderly reduction in the rate of inflation." At the December meeting "[c]onsiderable concern was expressed about the persistent weakness of key monetary aggregates despite the progressive easing of money market conditions in recent months."

In early 1971 the rapid acceleration was initially viewed as representing a make-up for the slower than desired growth rate in the fourth quarter of 1970 , when growth of money had slowed to a 3.8 percent rate. However, over the last half of 1970 money had grown at a 5.2 percent rate. Make-up for the fourth quarter slowdown in monetary growth was very rapid; money rose at a 9.4 percent rate in the first quarter and at an 11 percent rate in the second quater. From June 
1970 to June 1971 , money grew at a rapid 7.7 percent rate.

In the third quarter of 1971 , the early stage of the deceleration of money was viewed as a welcome offset to rapid growth over previous months of the year. At first the FOMC was reluctant to push for a more rapid growth of money. However, by the November 16 meeting, the FOMC clearly desired to reverse the trend growth of money. The Committee desired:

. . somewhat greater growth in monetary and credit aggregates over the months ahead, recognizing that pursuit of that objective might requife appreciably easier money market conditions.

Until mid-November the Desk moved cautiously within the money market directive to prevent rapid deceleration of money. Beginning in September, the Policy Record states that, in general, open market operations were directed at a gradual easing of money market conditions in light of the continuing tendency of the monetary aggregates to fall below expected paths.

As shown in Table I, money market conditions eased somewhat from September through December. However, until after mid-November easing was relatively gradual. The Federal funds rate, which averaged 5.53 percent between the late July and late August meetings, fell to only 5.09 percent, on average, prior to the mid-November meeting. The money stock did not respond to this cautious easing of money market conditions. There was no growth, on average, in money from mid-September to mid-December.

\section{Factors Influencing Money Growth in 1971}

In published explanations of the behavior of money growth last year the Federal Open Market Committee placed primary emphasis on factors that were asserted to determine the demand for money. The following quotes illustrate this view:

The rate of growth of both currency and privately held demand deposits rose because of considerably lower interest rates than earlier and the post-strike rebound in economic activity ["Financial Developments in the Finst Quarter of 1971 ," Federal Reserve Bulletin (May 1971), p. 368].

And the monetary aggregates expanded at rapid rates in the first quarter, with growth in $M_{1}$ (currency and private demand deposits) reflecting increased transactions demands and the lagged effects of previous declines in interest rates. [Monetary Policy and the U.S. Economy in 1971: A Prelude to the Anmual Report, Board of Governors, p. 6].

The monetary aggregates continued to expand at a strong pace in the second quarter of 1971. . . Primarily, however, the increase reflected the impact on transaction demands for money of the substantial expansion in expenditures that occurred in both the first and second quarters of the year and the lagged response of consumer demands for money to the sharp earlier decline of market interest rates ["Financial Developments in the Second Quater of 1971," Federal Reserve Bulletin (August 1971), p. $641]$.

Staff analysis suggested that the new economic program, along with other forces - including lagged reactions to earlier increases in short-term interest rates - should tend to produce lower rates of growth in the monetary aggregates over the rest of the year [Federal Reserve Bulletin (December 1971), p. 994].

At the time of the previous meeting of the Comr mittee it had been expected that growth in $M_{1}$ would slow from the average annual rate of 10 per cent recorded in the first 7 months of the year, in part in a lagged response to earlier increases in short-tem interest rates, and that $M_{z}$ would continue to expand at about the moderate rate that had emerged in July. For both measures, however, actual growth rates in August were lower than had been anticipated partly for reasons related to the flows of funds into foreign currencies. . . .

As at the previous meeting, staff analysis suggested that the effects of the new economic program on dernands for money, together with lagged reactions to earlier increases in short-term interest rates, should tend to produce much lower average rates of growth in the monetary aggregates over the rest of 1971 than had been recorded earlier in the year [Federal Reserve Bulletin (January 1972), pp. 36,37$]$.

It seems likely that the sharp slowing of $M_{3}$ growth in August was in large part attributable to the heavy ontflow of dollars into foreign exchange markets. Weakness continued in September, however, after the outtlow was severely cut back. This was apparently related to a reduction in demands for money balances in response to greater confidence and expectation of declining interest rates resulting from the President's new economic program ["Financial Developments in the Third Quarter of 1971," Federal Reserve Bulletin (November 1971), pp. 872-873].

Staff analysis suggested that the effects of two factors that had been tending in recent months to hold down demands for money - moderation of inflationary expectations as a result of the new economic program, and lagged reactions to the high short-term interest rates of late spring and early summer - probably had about run their course. According to the analysis, if money market conditions were similax to those prevailing or slightly easier, $M_{s}$, would begin to grow again in December and would expand faster over the first quarter - at a pace more nearly in line than recently with growing transactions demands [Federal Reserve Bulletin (February 1972), p. 139].

The rate of expansion in the narrowly defined money stock $\left(M_{1}\right)$, which had declined substan- 
tially in the third quarter from the very rapid pace established earlier in the year, slowed further to a modest 1 per cent annual rate of growth, as public demands for cash balances remained small in the wake of the very large build-up in liquidity over the first half of the year.

... $M_{i}$ may not have responded more sensitively to factors that generally promote growth in this aggregate, in part because the public decided to reduce precautionary balances built up earlier in the year when there was greater concern about the economic outlook. In addition, some money-holders may have been gradually shifting out of cash balances into interest-bearing assets in the belief that the wage-price control program would meet with success and that interest rates would be lower in the future. Finally, experience indicates that it takes time for the public to adiust its cash balances upward in response to lower short-term interest rates ["Financial Developments in the Fouth Quarter of 1971," Federal Reserve Bulletin (February 1972) pp. 95-96, $98]$.

\section{A Supply and Demand Analysis}

These propositions can be examined with demand and supply analysis. In Figures I-IV, the demand curve for money balances is represented by " $\mathrm{D}$ ", and the supply curve for money balances by "S". Quantities of money (M) demanded and supplied are expressed as dependent upon the current interest rate (i). Let us assume that the demand for money depends negatively on past values of the interest rate and positively upon growth of income as the previous quotes suggest. These factors operate to shift D. The money supply also depends on the monetary base. An increase in the base shifts $\mathrm{S}$ to the right and a decrease in the base shifts $\mathrm{S}$ to the left.

A couple of expositional points should be emphasized at this point. The money stock, quantity of money balances demanded and quantity of money balances supplied, is measured along the horizontal axis in Figures I-IV. The money supply and money demand refer to the curves labeled $S$ and $D$. A change in the money supply would appear as a shift in the curve labeled $\mathrm{S}$. The money stock is determined by the interaction of money supply and money demand. Values of the current interest rate are measured on the vertical axis of the graphs. ${ }^{*}$ As the interest rate rises the quantity of money supplied rises, even though the monetary base is unchanged; for example, banks reduce their excess reserves. In Figures I-IV this would appear as a movement along $S$. As the interest rate rises the quantity of money balances demanded decreases and this appears as at movement along $D$.

TThis analysis is based on conventional liguidity preference theory, Another analysis would include credit market conditions.
Lagged values of the interest rate enter as shift para meters in the demand for money function.

In Figures I-IV the size of the change in the money stock resulting from a shift in the demand for money depends upon the slopes of $D$ and $S$. If these curves have relatively steep slopes, as shown in the illustrations, then a shift in either $D$ or $S$ will have less of an effect on the money stock and relatively more of an effect on the interest rate than if the curves are drawn with fiatter slopes. Most empirical estimates indicate that the percent response of both the supply and demand for money balances to a percent change in short-term interest rates is small. This implies a relatively steep slope for each curve. Therefore, this analysis incorporates these empinical results.

Demand Factors - Over the first half of 1971, because interest rates had decined in the second half of 1970 and growth of income accelerated in the first half of 1971, the above analysis would suggest that the demand for money (D) shifted to the right from $D$ to $D^{\prime}$ as shown in Figure 1 . If the supply curve (S) is unchanged (that is, no change in the base), then the interest rate rises to it from $i$ and the money stock expands to $\mathrm{M}^{\prime}$ from $\mathrm{M}$.

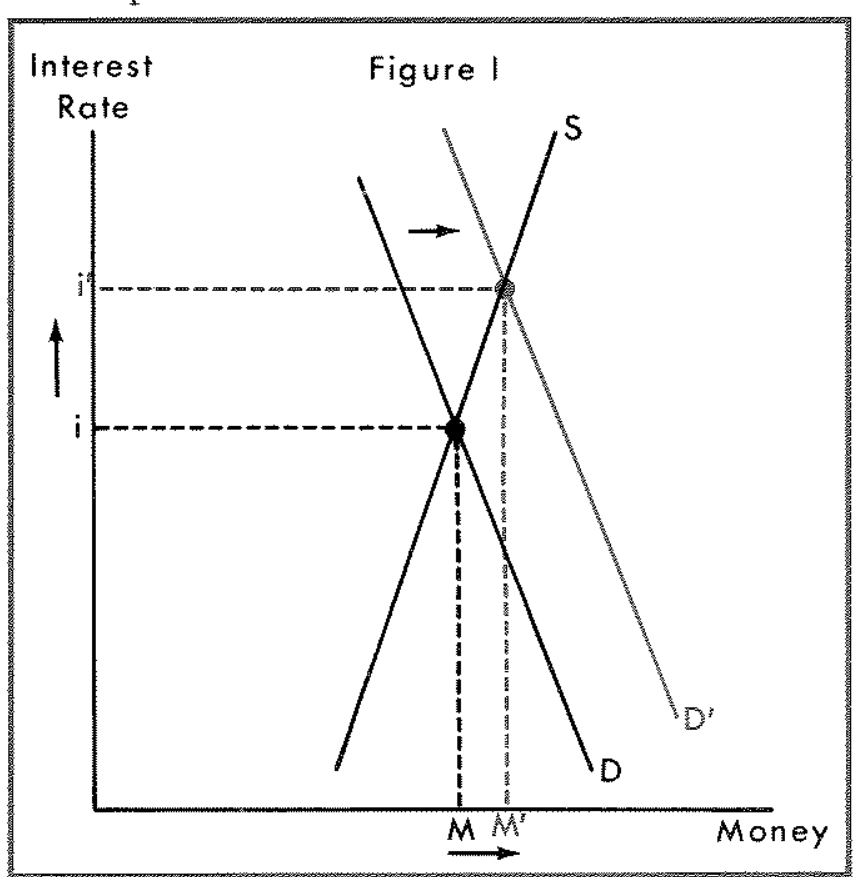

Interest rates rose in the first half of 1971 and growth of income slowed somewhat in the second half of the year. This would imply, following the conjectured relationship between lagged interest rates, income and the demand for money given in the above quotes, that the demand for money was shifting to the left during the second half of 1971, as illustrated 


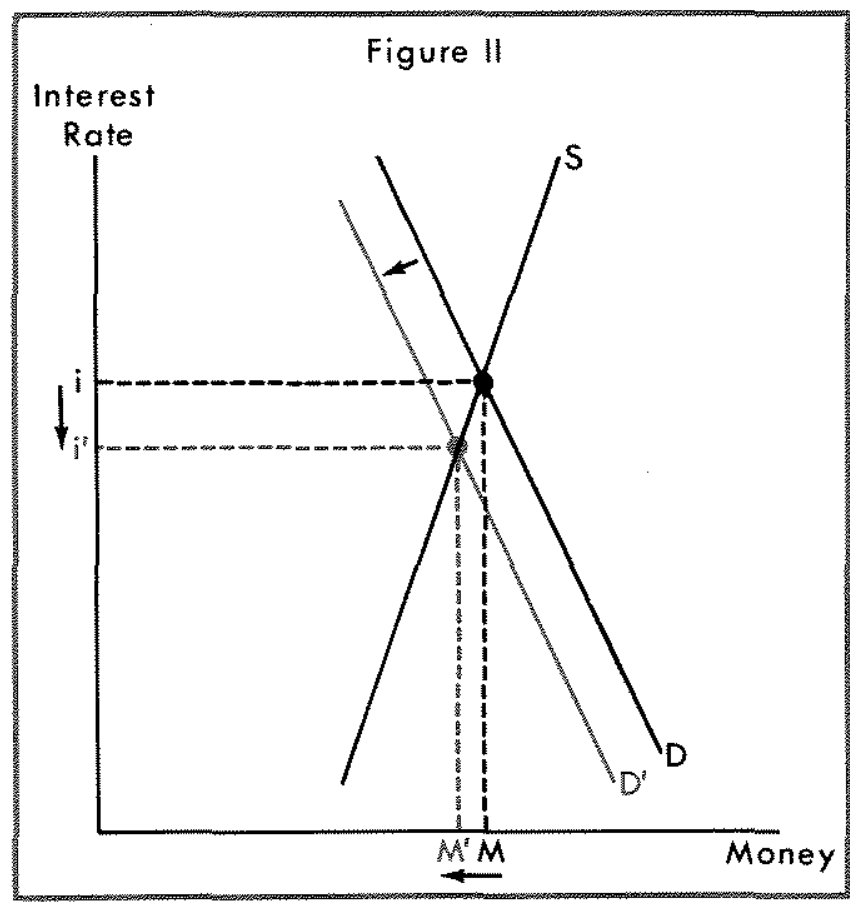

in Figure II. As the demand for money falls from D to $\mathrm{D}^{\prime}$, and if the money supply function (S) remains unchanged, then the interest rate declines from $i$ to $i^{\prime}$ and the money stock declines from $\mathrm{M}$ to $\mathrm{M}^{\prime}$.

If the supply of money ( $S$ ) is unchanged (that is, no change in the monetary base), then growth of the money stock that occurred was completely demand determined, as postulated in the above quotes. However, as long as the response of the money supply to changes in the base is not zero, then Federal Reserve open market operations which alter the growth of the base influence the supply of money, and hence, the money stock outstanding.

Supply Factors - Consequently, for a more complete analysis of money growth during 1971, behavior of the monetary base must also be considered. Growth of the base accelerated markedly during the first half of 1971 , then decelerated sharply in the second half of the year. Therefore, the explanations of Figures I and II must be broadened to include shifts in S.

Figure III illustrates the conditions for the first half of 1971 taking the supply factors into account. From December 1970 to July 1971 the monetary base grew at a 9.4 percent anntal rate. As the base grew rapidly, the money supply function (S) was substantially shifted to the right to $S^{\prime}$. Taking supply effects into account, the interest rate rises only to $i$ ", but the money stock expands to $\mathrm{M}^{\prime \prime}$ instead of only to $\mathrm{M}^{\prime}$.

Figure IV illustrates the case for the latter part of 1971. From July to December the monetary base grew

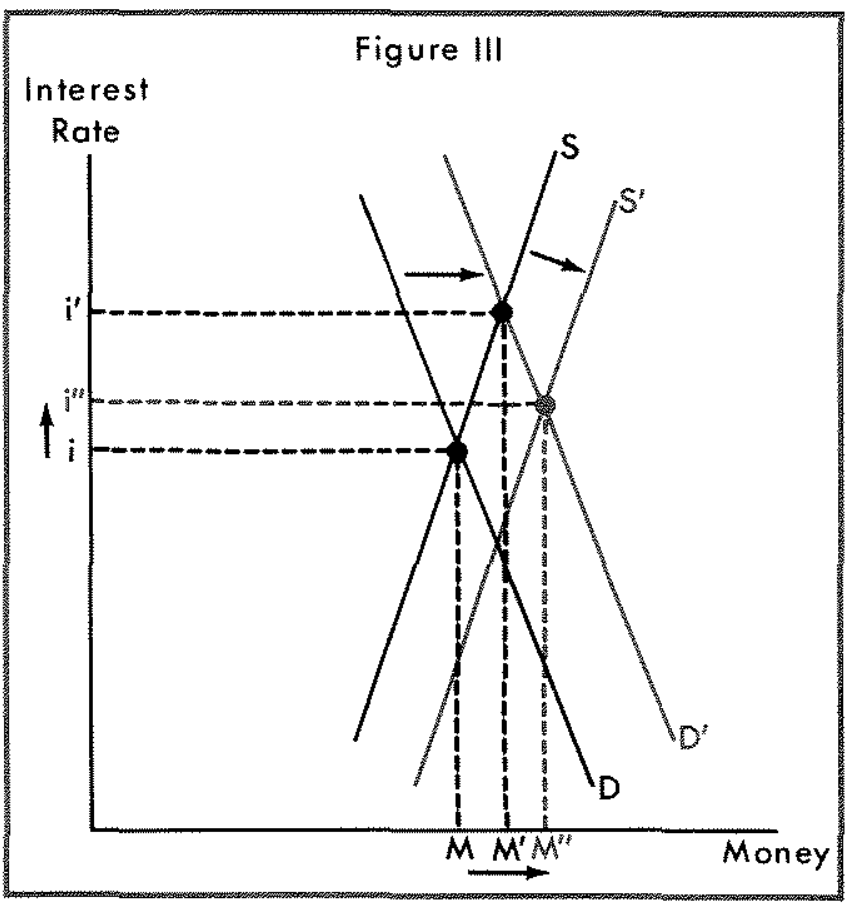

at only a 3.6 percent rate, and from September to December at only a 2.3 percent rate. The supply curve shifted only slightly to the right, as compared

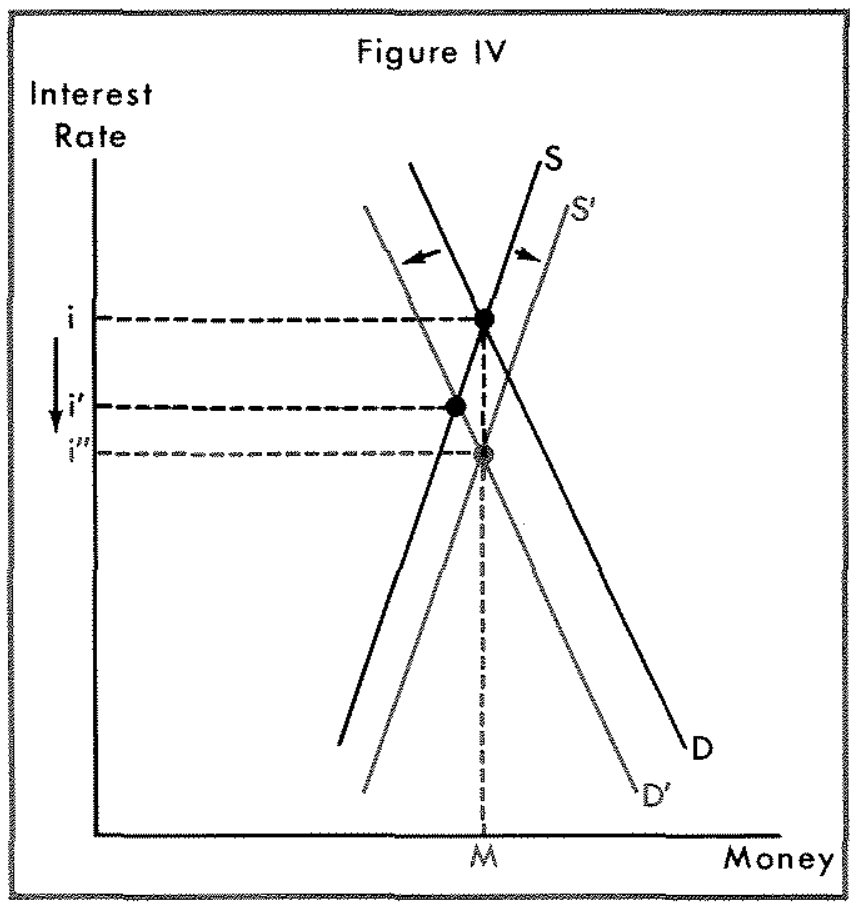

to the first half of the year, and the money stock remained at $M$ (no change) while market interest rates fell. ${ }^{8}$

${ }^{8}$ The money stock averaged $\$ 228$ billion in August 1971 and $\$ 228.2$ billion in December. 


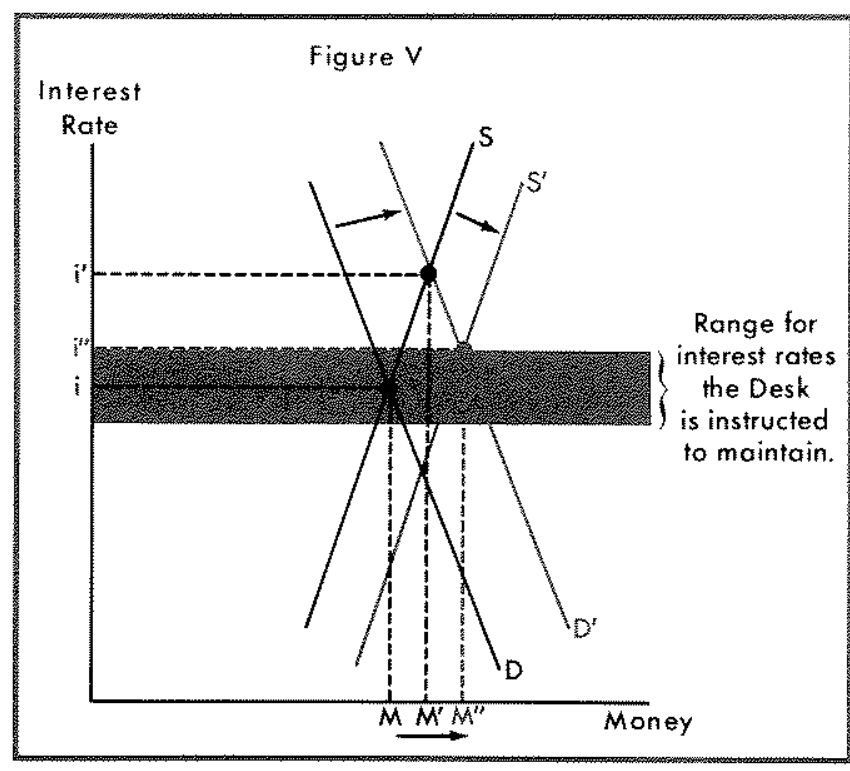

\section{Effect of Operating to Offset Changes In Interest Rates}

Figure $V$ may be used to illustrate problems that can arise in controlling the growth of money when the Desk is instructed to use open market operations to maintain a narrow range for short-term interest rates or permit only gradual changes in interest rates. Suppose that there is an increase in the money demand curve from $\mathrm{D}$ to $\mathrm{D}^{\prime}$, as illustrated in Figure $\mathrm{V}$, and the Desk has been instructed to prevent the interest rate from rising above $i^{\prime \prime}$. If no offsetting action is taken the interest rate will rise to $i^{\prime}$, above the upper bound of the Desk's instructions. To keep the interest rate below $i^{\prime \prime}$ the Desk would buy securities, which would increase the growth of the base and shift $S$ to $S^{\prime}$ as shown in Figure $V$. The interest rate temporarily rises only to i", but as shown in Figure V, money rises to $\mathrm{M}^{\prime \prime}$ rather than $\mathrm{M}^{\prime}$. Assuming the growth of income is positively related to the growth of money, then the growth of income accelerates, the demands for money and credit rise, and the Desk must again increase the growth of the base to prevent a further rise in interest rates. By reversing this analysis, it can be seen that if market rates are falling and the Desk is given instructions to operate within too narrow a range on the interest rate then the opposite situation could arise.

Therefore, FOMC instructions to the Desk to prevent demand induced changes in market interest rates result in amplifying the fluctuations in the rate of growth of the money stock. When in the face of demand induced changes in interest rates the FOMC gives the Desk instructions to maintain interest rates within a narrow band, the growth of the money stock can be considered demand determined. However, "demand determined" in this case has quite a different meaning from that in Figures $I$ and II where no change occurred in the money supply function, that is, no change in the monetary base. The money stock is demand determined in the case where the base changes because the Desk is instructed to resist demand induced changes in market interest rates which are not desired by the FOMC. In this circumstance the FOMC faces the decision of whether to control the growth of money or temporarily offset demand induced changes in interest rates. If the decision is made to control market interest rates, then the growth of money may deviate significantly from the expected growth rate.

The relative weights attached by members of the Committee to money stock growth and interest rates were given careful consideration in the decisions of the FOMC. For example, at the May 11 and June 29 meetings the possible short-run interest rate effects of open market operations necessary to substantially slow the growth of money influenced the decisions of the Committee.

\section{May ll Meeting}

In the discussion Committee members expressed concern both about the recent high rates of growth in the monetary aggregates and about the marked increases that had occurred in long-term interest rates. The view was widely held among members that expansion in $M_{1}$ at the first-quarter pace for an extended period would be inconsistent with an orderly reduction in the rate of inflation. Also widely held, however, was the view that sharp increases in long-term rates at this juncture might have adverse consequences for spending, particularly in the residential construction and State and local government sectors, and might thus pose a threat to the economic recovery under way.

Although there were some rather marked differences in the stress that individual members placed on these two types of considerations, the Committee agreed that it would not be desirable at present either to revert to the money market conditions that had prevaled until the end of April or to seek the amount of firming that evidently would be required to achieve a substantial slowing of growth in the aggregates over to the second quarter.

\section{June 29 Meeting}

In the Committee's discussion considerable concern was expressed about the rapid growth in the monetary aggregates, particularly in light of the persistence of inflationary pressures and expectations. At the same time, concern was expressed about the recent upward pressures on interest rates, in view of the dependence of the current economic recovery on continued expansion in such interest-sensitive sectors of the economy as residential construction. 
Dote of

FOMC

Meeting

January 12

\section{Policy Consensus}

In light of the foregoing developments, it is the policy of the Federal Open Market Committee to foster financial conditions conducive to the re sumption of sustainable economic growth, while encouraging an orde

Dissents:

$$
\begin{aligned}
& \text { Dissents: } \\
& \text { Mr. Franeis }
\end{aligned}
$$

February 9 No Change

$$
\begin{aligned}
& \text { Dissents: } \\
& \text { Mr. Francis }
\end{aligned}
$$

March 9 No Change

\begin{tabular}{|c|c|}
\hline April 6 & $\begin{array}{l}\text { In light of the foregoing developments, it is the } \\
\text { palicy of the federal Open Market Committee to } \\
\text { foster financial conditions conducive to the } \\
\text { resumption of sustainable econamic growth, } \\
\text { while encouraging an orderly reduction in the } \\
\text { rate of inflation, moderation of stort term capi- } \\
\text { tal outhows, and attainment of reasonable } \\
\text { equilibrium in the country's balance of payments. } \\
\text { Dissents: } \\
\text { Mr. Hayes } \\
\text { Mr. Kimbrel }\end{array}$ \\
\hline May 11 & $\begin{array}{c}\text { No Change } \\
\text { Dissents: } \\
\text { None }\end{array}$ \\
\hline
\end{tabular}

$$
\text { None }
$$
equilibrium in the country's balance of poyments.

\section{Operating Instructions}

To implement this policy, the Committee seeks to promote accommodative conelitions in credit markets and moderate expansion in monetary and credit aggregates. System open market operations until the nex meeting of the Committee shall be conducted with a view to maintaining benk reserves and money market conditions con sistent with those objectives, faking account of the forthcoming Treasury finencing.

. System open market operations until the next meeting of the Committee shall be conducted with a view to mainfaining prevailing money market conditions while accommodating term rates;

System open market operations until the mex meeting of the Committee shall be conducted with o view to maintaining prevailing money market conditions while accommodaling any dowaward movements in long-ferm rates;

- while taking account of the Treasury financing the lerms of which are to be announced late in the month, System open market operations until the next meeting of the Cammittee shall be conducted with a view to oftaining emporarly some minor nrming in mon matket condiions, while cantinuing to meet some part of reserve needs markets;

. . the Committee seeks to moderate growth in monetary and credit aggregates over the months ahead, taking account of the current Treasury financing, developments in capital markets, and uncertainties in foreign exchange markets. System open market operations unfil the next meeting of the Commitee shall be aimed initially at main faining eurrently prevailing money market conditions, and thereafter conducted with a view to maintaining bank

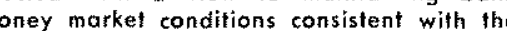
above-cited objectives.

June 8 No Change

$$
\begin{aligned}
& \text { Dissents: } \\
& \text { None }
\end{aligned}
$$

the Committee seeks to moderate growth in monetary aggregates over the months ahead taking account of developes the deverations until the next meeting of the Committee shat be conducted with view to achieving bank reserve and money market conditions consistent with those objectives.

\section{Proviso Clause of Directive}

no proviso clause

provided that money market conditions shall promptly be eased somewhat further if it appears that the monelary aggregates are falling shors of the growth path

provided that money market conditions shall be modin fied if it appears that the monetary and credit aggre. gates are deviating significantly from the growth paths expected.

provided that money market conditions shall be modifed if it appears thot the monetary and credit aggrefed if it appears that the monetary and credit aggredesised.

no provisa clause

no proviso clause 
No Change
Dissents:

$$
\text { None }
$$
July 27 In light of the foregoing developments, it is
the policy of the Federat Open Market Com. mittee to foster financial conditions conducive to sustainable economic growth, while encouraging an orderly reduction in the rate of infation, moderation of short-term copilat outfows, and attainment of reasonable equilibritum in the country's bolance of poyments.

Dissents:

light of the foregoing developments, it is the policy of the federal dopen Markef com the poltcy of the rederal open Markef Com with the gims of the new governmental program with the alms of he new governmental program, increased employment, abatement of inflationary pressures and attainment of reasonoble equilibrium in the country's balonce of payments.

$$
\text { Dissents: }
$$

September 21 No Change

$$
\begin{gathered}
\text { Dissents: } \\
\text { None }
\end{gathered}
$$

No Change
Dissents:

$$
\begin{aligned}
& \text { None } \\
& \text { Nons: }
\end{aligned}
$$

\section{November 16 No Change}

$$
\text { Dissents: }
$$

\section{None:}

December 14 No Change
Dissents:

$$
\text { None }
$$

SOURCE: "Reeord of Policy Aetiong" of the Federal Open Market Cornm
serve Bulletin
.. The Committee seeks to achieve more moderate growth in monetary aggregates over the months ahead, taking account of developments in capital markets. System open markef operations until the next meefing of the Committee shall be conducted with a view to achieving bank reserve and nin

faking account of the current Treasury financing and of developments in capital markets, the Committee seeks to achieve mote moderate growth in monetary aggregates over the monihs ahead. System open market operotions until the next meeting of the Committee stall be conducted with a yiaw to achieving bank reserve and money market conditions consistent with those objectives.

- the Committee seeks to achieve more moderate growth in monetary and credit aggregates over the months ahead. System open market operations until the nexk meeting of the Committe shall be conducted with a view consistenk with that objective. monelary and credit aggregales, taking account of developments in capital markets. System open market operations until the next meeling of the Commitee shall be conducted with a view to achieving bank reperve anc

. The Committee seeks to achieve moderate growth in monetary and credit aggregates over the months ahead. System open market operations until the next meefing of the Commitlee shall be conducted with a view to athieving bank reserve and money markef conditions consisten! with that objective, faking account of the forthcoming Treasury financing.

- The Commintee seeks to promote somewhat greater growth in monetary and credit aggregates over the months ahead. System open market operations until the next to arhieving benk reserve and money maket conditows consistent with that objective.

. . Fhe Committee seeks to promote the degree of ease in bank reserve and molfey market conditions essential to greater growfls in monetary aggregales over the months ahead, while taking accoun of international developments. *

Wubseguent to the December meeting, on December $20,5971$. nomic policy directive by adding the clarse "while taking aceount of international developments." no proviso clause

no proviso clause

no proviso cliquse

no proviso elause

no proviso cloyse

no proviso elause

no proviso clause 
While the members agreed that an unduly sharp firming of money market conditions should be avoided because of the risk of undesired repercussions on market interest rates, the Committee decided that open market operations in the coming period should be directed at achieving more mod erate growh in monetary aggregates over the months ahead. As at the preceding meeting, it was agreed that account should be taken of developments in capital markets in the conduct of operations.

Every open market operation, regardless of its purpose, affects the base. Open market operations aimed at offsetting market determined movements in interest rates result in accelerations or decelerations of the growth of the base and hence, shifts in the money supply function. If greater short-run variations in interest rates were permitted, the FOMC would be better able to control the growth trend of money.

\section{Money, Base, and Money Market Conditions}

Movements in the base paralleled movements in the money stock in 1971, as shown in Table II and the accompanying chart. This close relationship between growth of the monetary base and money is not unique to this period. Table II also presents the pattern of movements in the base and money over the recent periods of sharp accelerations and decelerations.

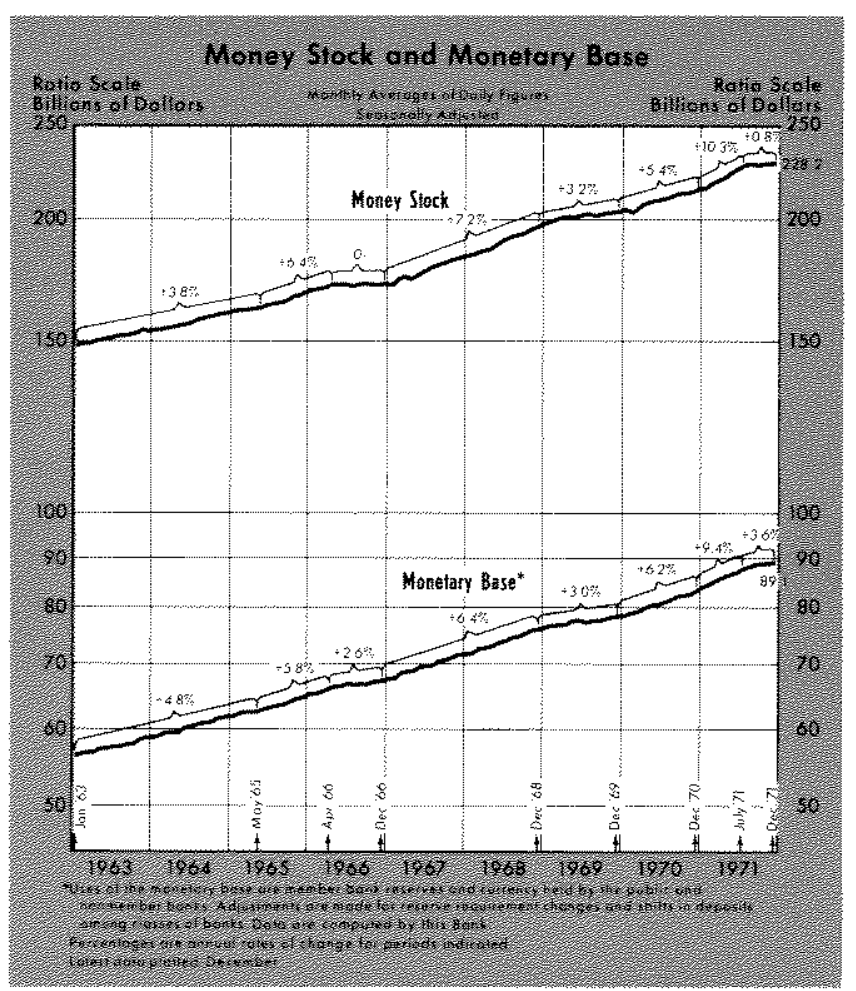

Federal Reserve actions, primarily open market operations, dominate the growth pattern of the mone-

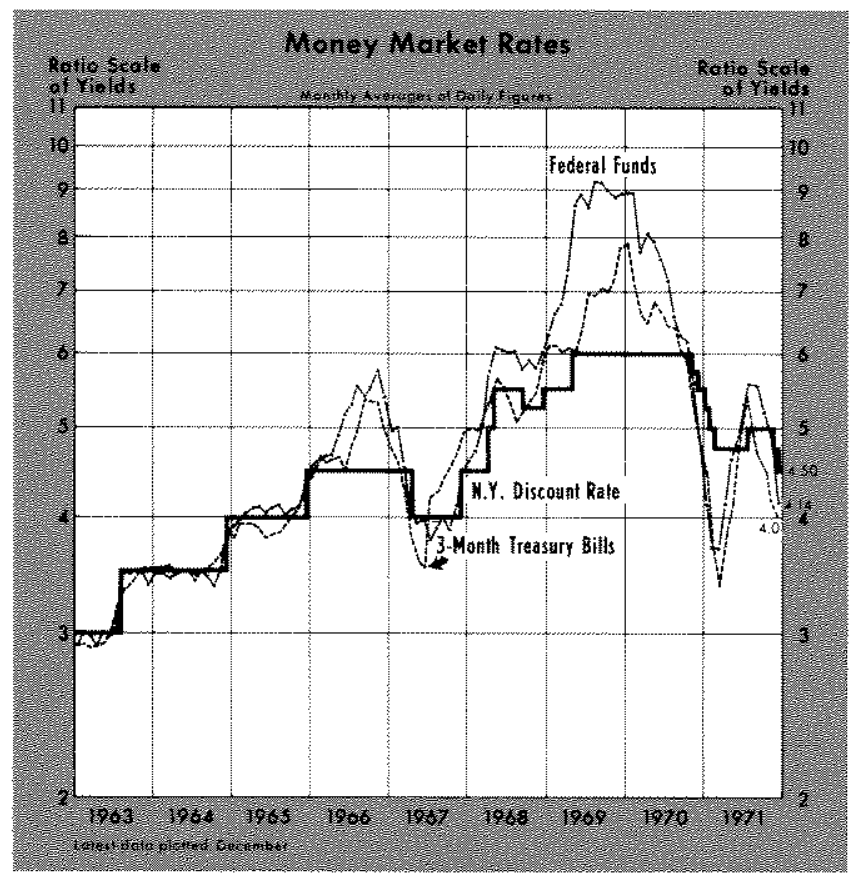

tary base. Over any period of time, there will be a set of money market conditions, a growth rate of base, and a growth rate of money consistent with a given comse of open market actions. However, open market operations that achieve a set of money market conditions desired by the Committee may not be consistent with a growth of the base necessary to achieve the growth rate of money also desired by the Committee.

As shown in Table $I$, money market conditions fimed in the period March through July. However, as shown in Table II, the growth rate of the base accelerated from 8.4 percent in March to 10 percent in May and then remained at about a 9 percent rate through July. Such a growth path for the base clearly did not imply a much slower growth of money. Over the second half of the year money market conditions eased markedly, but the base decelerated drastically. The growth path of money paralleled the growth path of the monetary base, not the pattern of money market conditions.

The situation where the growth pattern of money deviated from that expected from specified money market conditions is not a situation peculiar to 1971 . This same pattem can be traced in the Policy Record of the FOMC in prior years. ${ }^{10}$

\footnotetext{
POther Federal Reserve actions that influence the monetary base include Federal Reserve lending to membr banks and changes in member bank reserve requirements.

10See Reprints 22, 28,39,57 and 68 for annual reviews of monetary actions by the FOMC for the years 1960-70, available on request from this Bank. See also Brimmer, "The Political Economy of Money," pp. 48-53, for a discussion of the problems encountered in 1966.
} 


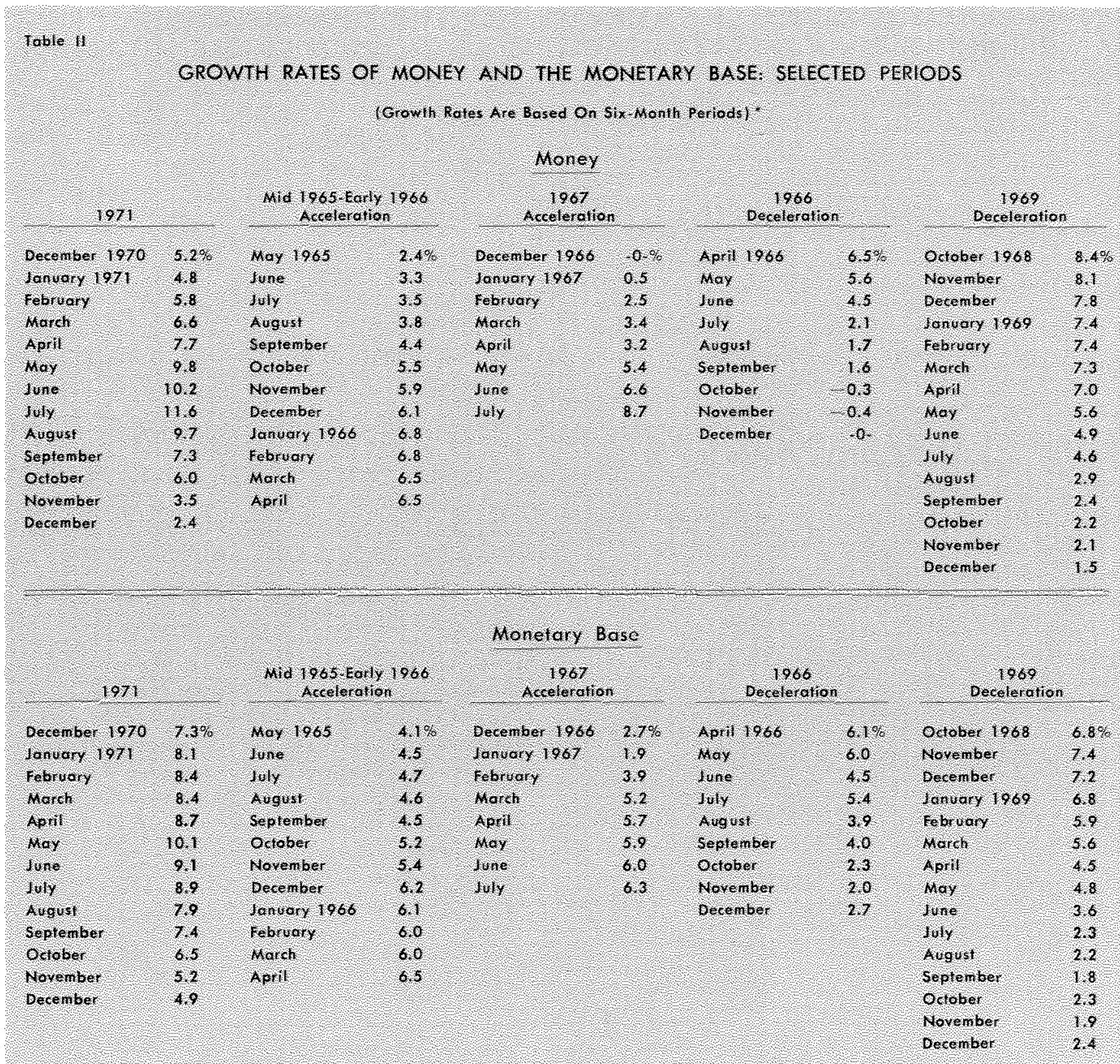

Tron,

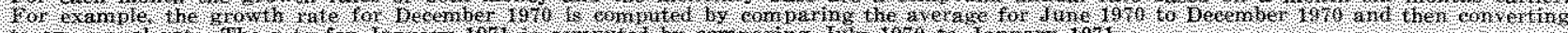

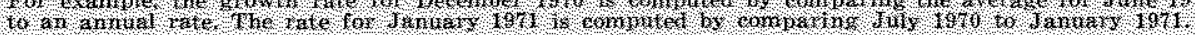

\section{Long-Run Compared To Short-Run Effects of Changes in the Growth of the Base}

When implementing monetary policy, a careful distinction has to be made between the short-run effect of a change in the base and the longer-run effects of such actions. The short-run effect of accelerating the growth of the base is to lower market interest rates, while a deceleration of the base puts upward pressure on market rates and results in firming of other money market conditions. However, longer-run effects of such actions are opposite from their initial effect. For example, stupose that market rates are moving upward and the FOMC decides to resist such a trend. The Desk may be instructed to maintain prevailing money market conditions; in other words use open market operations to resist a further rise in market rates. To do so, the Desk probably would have to accelerate its purchase of securities, and thus growth of the base would accelerate. The initial effect would be to slow or to lower market interest rates. 
This acceleration of the base leads to an acceleration in the growth of money, and over time total spending rises more rapidly. An increased demand for credit develops, and thus additional upward pressures on market interest rates follow. "Maintaining existing money market conditions," or even permitting only "some moderate fiming in money market conditions" may require a further accelention in the base. This process creates severe problems when the FOMC attempts to control the growth of money by using a money market strategy.

If money market conditions are firmed enough to actually slow the growth of the base, then the growth of money slows. However, if the slowdown of money is maintained, then longer-rm effects of this policy on income and the demand for credit lead to falling market rates and easier money market conditions. As rates fall the FOMC may reason that its open market operations have caused the easing in the money market and that the decline in market interest rates indicates that open market operations are exerting a more expansionary (or less restrictive) effect on their policy objectives. The FOMC may therefore be reluctant to increase its purchases of securities to halt a rapid deceleration of the base. Again, from a money market operating strategy, it appears the Desk is attempting to achieve a reversal in the growth trend of morey. However, from an analysis that emphasizes growth of the base as the primary determinant of the growth of money, the money market operating strategy again spells considerable problems for money control. ${ }^{11}$

\footnotetext{
1 These results are implied by considerable theoretical and empirical research. For exanole, in a study of several large econometric models Professor Joseph R. Zecher found the following (where $B$ a denotes the net source base or nonborrowed base):
}

(1) Although the adjustment patterns differ among the models, ail of the models imply that in the second and later quarters after the change in $B^{\text {a }}$ the responses of both the short-tem interest rate and the long-term interest rate decay rapidly.

(2) Using Ba to control the term structure of interest rates is effective only in the quarter of the policy action. By the second auarter most of the effect of the policy action disappears and may actually be reversed if income is especially responsive to changes in $B u$.

(3) A constant interest rate policy has the following characteristics according to these models: (a) control of demand deposits is forfeited in the quarter in which the policy is instituted: (b) control of time deposits is forfeited after the first quarter; and (c) the sharp reversal of the response to Ba after the first quarter, and the resulting shift in the relative infuence on the shortterm interest rate of the initial changes in $B: a$ and income, make the conduct of an interest rate policy in succeeding quarters increasingly complicated.

See Joseph F. Zecher, "An Evaluation of Four Econometric Models of the Financial Sector, Dissertation Series Number 1 in Federal Reserve Bank of Cleveland Economic Papers (January 1970). The models studied were two versions of a

\section{Conclusions}

To attain its policy objectives in 1971 the FOMC sought to use open market operations to achieve moderate growth rates for the monetary aggregates and moderately dechining interest rates. However, if one looks at the pattern of interest rates or the growth of money over 1971 both these series resemble a roller coaster. Market rates fell early in the year, reversed their course in February and March, then rose rapidly until carly August when they began a rapid decline that carried into 1972. The growth of the money stock accelerated at extremely rapid rates over the first half of the year then decelerated at very rapid rates over the second half of 1971 .

The Committee's intermediate objectives for interest rates and growth of the monetary aggregates were often in conflict in 1971. One conclusion of this article is that the operating strategy based on allowing only small changes in money market conditions in seeking to avoid possible undesired movements in long-term rates resulted in sharper aceelerations and decelerations in the growth of money in 1971 than desired by the FOMC. The problems of trying to implement monetary policy with money market conditions as the primary target of open market operations had been forcefully brought to the Committee's attention by the Maisel Committee Report completed in early March $1970 .{ }^{12}$ The report was not adopted formally by the FOMC, nor has it been published. However, the general content of the Maisel Report may be obtained from a speech by Governor Brimmer:

In general, the issue the Maisel Committee focused on is the one already identified: if money market conditions are the primary target of open market operations, the FOMC has no clear and definitive way of giving instructions to the Manager of the

model by Ronald L. Telgen, the Brookings model financial section, and the FRB-MIT model group. Results similar to the first item cifed above were also obtained using the Ando-Goldfeld model in Zecher, "Implications of Four Econometric Models for the Indicator Issue," American Economic Review (May 1970), pp. 47-54, especially Table 3, p. 50. Also see William E. Gibson, "The Lag in the Fifect of Monetary Policy on Incone and Interest Rates," Quarterly Journal of Economics (May 1970), pp. 288-300; William P. Yohe and Denis S. Karnosky, "Interest Rates and Price Level Clanges, 1952-69," this Review (December 1969), pp. 18.38 ; and Albert E. Burger, "The Implementation Problem of Monetary Policy," this Reciew (March 1971), pp. $20 \% 30$.

t2The Masel Committee was a Subcommittee aposointed by Chairman Martin in the Spring of 1969 for the purpose of exploring means of improving open market operations. The Committee was under the leadership of Govemor Sheman Maisel and also included Presidents Frank Morris (Boston), and Eliot Swan (San Francisco). Eapers prepared for the Maisel Conmittee are available in Open Market Policies and Operating Procedures - Staff Studies, Board of Covemors of the Federal Reserve System, 1971. 
SOMA [System Open Market Account]. If he achieved specified goals in terms of interest rates and other money market conditions, he had no sure way of reaching the Commiteee's objectives with respect to bank credit and the money supply. The reverse is also true. Thus, given this conflict, the need for basic reform of the FOMC's approach to monetary managenent was indicated. ${ }^{\text {it }}$

Past experience with a money market operating strategy has not led to stable interest rates and has frequently resulted in a discrepancy between actual and desired growth rates of money. Prolonged rapid increases and decreases of the money stock that accompanied this strategy, through their effects on total spending, price expectations and conseguently the demand for credit, have been a major factor in the marked fluctuations in market rates during the past six years. Also, sharp accelerations and decelerations of the monetary base which have been necessary at times to offset wide swings in the growth of money have induced short-rum instability into the money market.

If the growth of the money stock in 1971 was com* pletely demand determined (no shift in the money

13Brimmer, "The Political Economy of Money," pp. $59-60$. supply), then this would imply that very substantial shifts occurred in money demand in 1971. Although the evidence is not conclusive on the stability of the demand for money, there is very little evidence that suggests it is subject to very frequent and erratic shifts. ${ }^{1+}$

During 1971 the FOMC, on balance, resolved the conflict between their desired path for interest rates and their desired growth paths for monetary aggregates by cautiously adjusting money market conditions and hence accepting greater accelerations and decelerations in money than they initially desired. The resulting open market operating strategy led to a rapid growth of the monetary base in the first half of 1971 and a rapid deceleration in the growth of the base in the latter part of 1971 . Although changes in the demand for money may have exerted some direct influence on growth of the money stock, changes in the supply of money induced by these marked changes in the growth of the monetary base were the dominant infuence on the growth of money in 1971.

1.See David E. W. Laidler, The Demand for Money: Theories and Evidence (Scranton: International Textbook Co., 1969), pp. 105-106.

\section{SUPPLEMENT}

\section{Federal Open Market Committee Decisions - 1971*}

The Federal Open Market Committee met thirteen times during 1971 to review and evaluate developments in the economy, and to prescribe what objectives open market operations should try to achieve until the next FOMC meeting in order to further the longer-run goals of monetary policy. The 1971 FOMC meetings are grouped into three periods. The decisions of January through April were conditioned by the shortfall of money in the fourth quarter of 1970 and by an explicit desire for lower long-term interest rates. The directives of the May through August meetings called for more moderate growth of monetary aggregates, although aggregates grew rapidly during most of the period. The directives of the September through December meetings called for moderate or somewhat greater growth in monetary aggregates, yet money was almost unchanged over the period.

\section{January Through April: Desire For Moderately Expansive Monetary Actions}

The Committee desired that monetary actions accommodate the economic recovery which was expected to occur in the first quarter. Early in this period, several members of the Committee were concerned about the

\footnotetext{
"Data presented are those available to the Committee at the particular meeting. Subsequent revisions may have occurred in some figures.
}

slower than desired growth in money in the fourth quarter of 1970 and also desired to see further dechines in long-tem interest rates. Money market rates fell substantially during January and February.

Begimning in February, money began to grow very rapidly and several long-term interest rates began to rise. At the last three meetings of this period, the Committee called for accommodation of any decline in longtem rates. Proviso clauses were added to the directives calling for an adjustment of money market conditions should the growth of aggregates deviate significantly from the desired paths.

\section{January 12 Meeting}

The 1970 recession was dearly in evidence at this meeting. For example, real GNP was expected to show a decline in the fouth quarter of 1970 , largely due to the automobile industry strike. The unemployment rate rose to 6 percent in December 1970 , and the U. S. trade balance was reported to have deteriorated further in November. The fourth quarter deficit in the balance of payments on a liquidity basis was estimated to be about the same as in the third quarter, that is, about $\$ 3$ billion.

Projections by the staff of the Board of Governors indicated a sharp recovery would begin in the first quarter, primarily as a result of a resumption of auto 


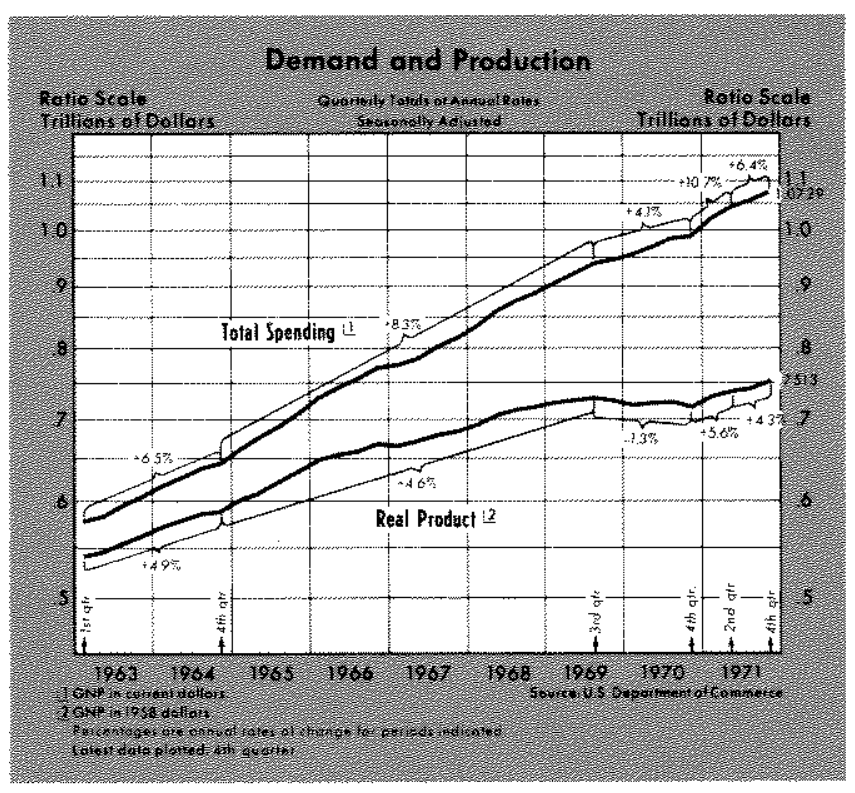

production. The rate of increase of real GNP was expected to slow in subsequent quarters. Part of the strength in the economy was expected to come from residential construction and state and local spending. Consumer expenditures were expected to increase only moderately, apart from the anticipated return to a higher rate of new car purchases early in the year, while defense spending and fixed investment were not expected to bolster economic activity over the first half of the year.

Although money growth viewed over a longer time period was about in line with the desired rate, a shortfall had occurred in the fourth quarter of 1970 . The Committee had desired a 5 percent rate of money growth, compared with an actual rate of 3.8 percent. Analysis presented to the Committee at the January meeting indicated more easing of money market conditions would be necessary in order to expand $M_{1}$ in the first quarter at a 7.5 percent rate. The Committee decided to seek "some moderate easing of money market conditions." Although a proviso clause was not directly included in the directive, the "Record of Policy Actions" indicates that members desired enough easing in money market conditions to be able to make up for the slower fourth quarter growth in money.

Mr. Francis dissented from this decision. He desired a continuation of a 5 percent growth rate of money, which was about the average rate in the second half of 1970. With this rate of growth of money he felt that the "longer-run performance of production and prices would be better than if money were to expand at some faster rate." In addition, he desired less emphasis on money market conditions in implementing open market operations.

\section{Februany 9 Meeting}

Some renewed evidence of upward pressure on prices was given at this meeting. The consumer price index rose considerably in December, and wholesale prices

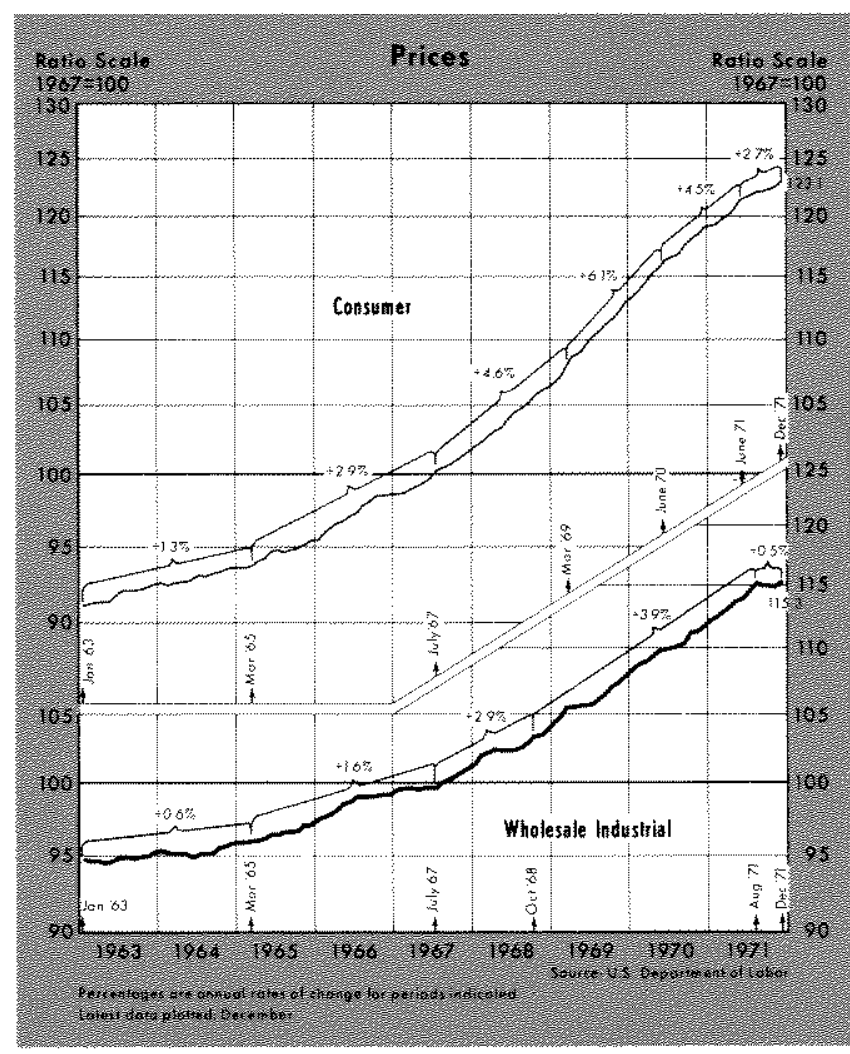

rose rapidly in January, due in part to an increase in agricultural prices.

Following the January meeting both long- and shortterm interest rates fell, which was thought to reflect the reports of weak economic activity and market expectations of lower rates which had been buttressed by reductions in the prime lending rate and the discount rate. It was noted at this meeting that money had increased less in January than had been expected earlier. The Policy Record stated that oper market operations had been aimed at somewhat easier money market conditions initially after the January meeting, and then sought more easing as money fell short of Committee expectations.

Even with the slow January increase, growth of money was expected to be at about a 6 percent annual rate in the first quarter, assuming the prevailing money market conditions were maintamed. Although the Committee agreed to "accommodate further declines in long-term interest rates," the February "Record of Policy Actions" reported that members of the Committee differed in their views concerning objectives for money and shortterm credit markets and monetary and credit aggregates. Some members continued to want more easing in money market conditions, while other members wanted these conditions unchanged in view of the recent and prospective rapid growth of monetary aggregates other than money and the undesirable consequences of lower shortterm rates for intemational capital flows. Also, some members expressed a desire for less emphasis on short-run fluctuations in money in the period ahead.

The Committee directed open market operations to "be conducted with a view to maintaining prevalling 


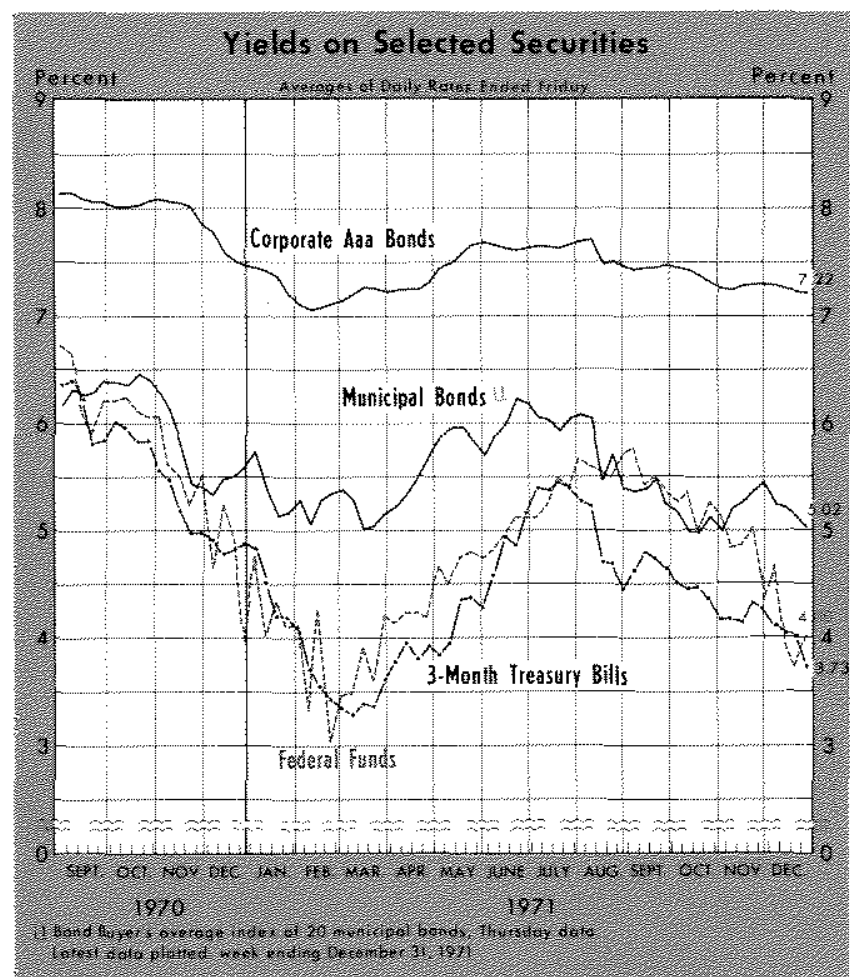

money market conditions while accommodating additional downward movements in long-term rates." In addition, the Committee added a proviso clause stating that it desired to have money market conditions "promptly" eased if growth of monetary aggregates fell below their desired paths. "The Committee also agreed that its objectives for interest rates would be facilitated if, to the extent feasible, needs to supply reserves were met by purchases of longer-term Treasury securities."

Mr. Francis dissented from the February directive for reasons similar to those at the previous meeting. Namely, he preferred a 5 percent growth rate for money and less emphasis on money market conditions in implementing monetary policy.

\section{March 9 Meeting}

Yields on new issues of corporate and municipal bonds began to rise in early February, although short-term rates continued to fall. Severnl Committee members expressed concern about the increases in long-term rates. The desirability of renewed declines in long-term rates was generally agreed upon, but it was also recognized that "further sizable declines in short-term interest rates would not serve a useful purpose." Some members indicated a desire to have some modest increase in shortterm rates in view of recent large capital outllows and the expected rapid growth of monetary and credit aggregates.

At the March meeting it was noted that $\mathrm{M}_{1}, \mathrm{M}_{2}$ and the adjusted credit proxy grew more rapidly in February than had been expected at the previous meeting. Analysis presented at the March meeting indicated $M_{1}$ would grow at about a 7 percent annual rate in the first quarter of 1971 if prevailing money market conditions were maintained, and that a more rapid rate could be expected in the second quarter.

Various views were expressed in regard to the emphasis that should be given monetary and credit aggregates and on the appropriate rate of growth for these aggregates. Some members were concerned about the projected rapid growth of aggregates in the second quarter. Others "stressed the uncertainties attached to the projections... and indicated that they were not disturbed by the near-term outlook for the aggregates."

The directive called for "maintaining prevailing money market conditions while accommodating any downward movements in long-term rates." A proviso clause was also included stating that money market conditions should be modified if it appeared the expected growth paths were not achieved for monetary and credit aggregates.

\section{April 6 Meeting}

Real GNP was reported at this meeting to have risen substantially in the first quarter; however, unemployment moved back up to 6 percent. Slower real GNP growth was still expected in the second quarter, prim marily due to slower growth in sales of motor vehicles and a decline in deferse expenditures. The outlook for the second half of 1971 was clouded by the possibility of a steel strike, but assuming a strike of no more than 60 days, projections indicated the growth of real GNP would be somewhat higher than the anticipated growth for the second quarter.

The U. S. foreign trade account showed only a small surplus in January and February. The deficit in the balance of payments on the liquidity basis was expected to be much larger in the first quarter than in the second half of 1970 , while on an official settlements basis the firstrquarter deficit in the payments balance was exceptionally large. These deficits were bolstered by heavy capital lows of interest-sensitive funds.

Following the March meeting, short-term interest rates began to rise. For example, 3-month Treasury bill rates rose about 40 basis points. After rising considerably in previous weeks, yields on new corporate and municipal bonds fell after the March meeting, then later on began to advance again. Both $M_{1}$ and $M$ were reported to have increased considerably more than had been expected at the previous meeting, while the adjusted credit proxy grew less rapidly than was expected. It was estimated that $M_{1}$ grew at about an 8 percent annual rate in the first quarter, $M_{2}$ at a 17.5 percent rate, and the adjusted credit proxy at an 11 percent rate. In response to the "considerably faster than expected" growth of $\mathrm{M}$ : and $\mathrm{M}_{2}$, some "slight firming of money market conditions" was sought after the March meeting.

Under the assumption of maintaining prevailing money market conditions, analysis indicated $\mathrm{M}_{\mathrm{I}}$ would grow even faster in the second quarter than the 8 percent in the previous quarter. Growth of various time deposits, however, was expected to slow substantially, leading to moderation in the growth of $\mathrm{M}_{2}$ and the credit proxy. The Committee agreed that open market operations should be aimed at "attaining temporarily some minor 


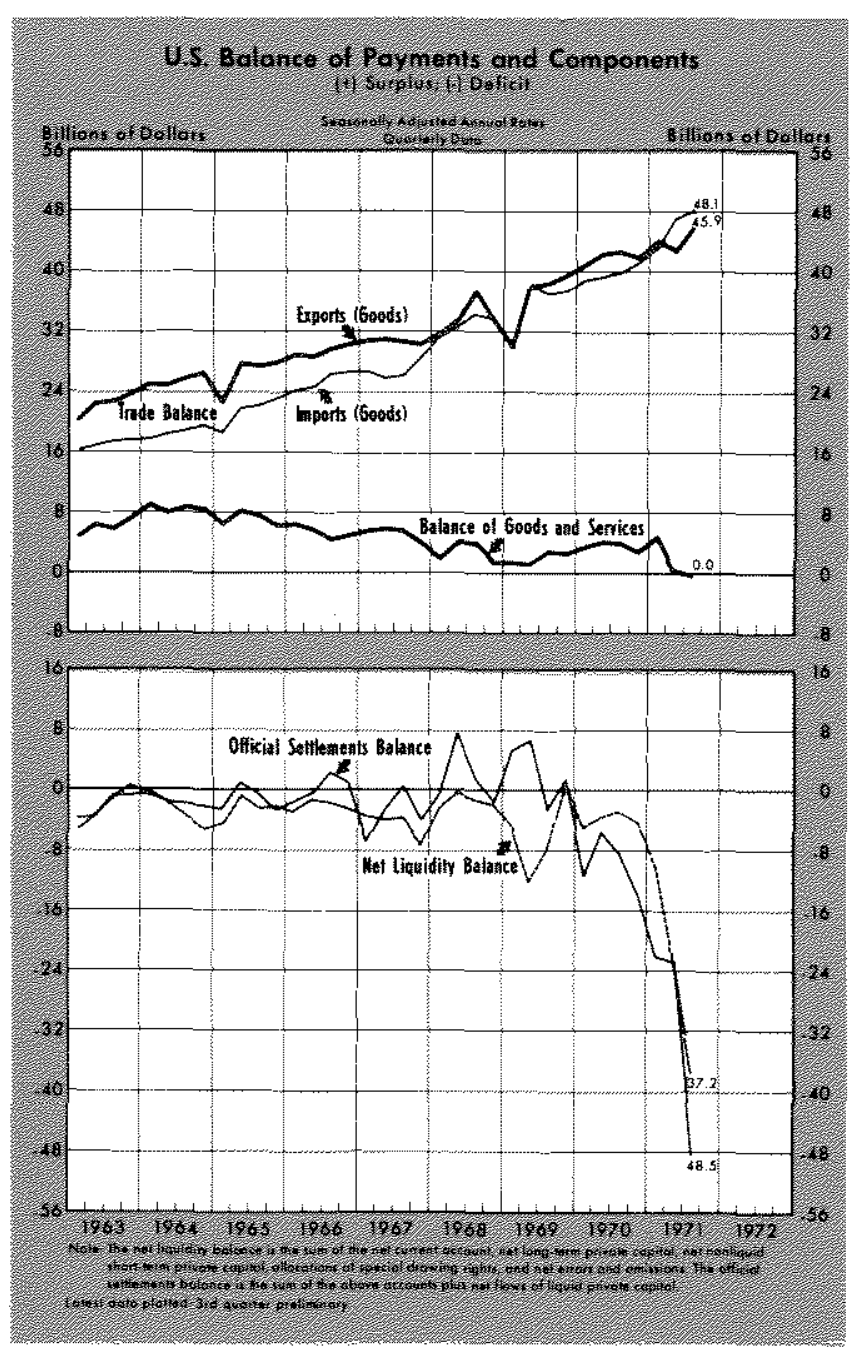

firming in money market conditions." Some members wanted this firming in order to narrow the difference between short-term interest rates here and abroad so as to moderate capital ouflows. The Committee stated its desire to have "more moderate expansion in the monetary aggregates in the second quarter than had occurred in the first," that is, less than 8 percent.

Two members dissented from this directive, favoring in both cases "more firming of money market conditions" than implied in the Committee's directive. $\mathrm{Mr}$. Hayes thought there was a "need for moving toward somewhat higher short-term interest rates in light of the international financial situation" as well as the "risk of excessive growth in the money stock." Mr. Kimbrel thought "higher short-term interest rates would be desirable mainly to hold growth in the monetary and credit aggregates to a moderate pace in order to avoid a rekindling of inflationary expectations."

The "Record of Policy Actions" for the May 11 meeting states that initially after the April meeting "some" what firmer conditions in the money market" were sought. Then as aggregates, primarily $\mathrm{M}_{1}$, yrew faster than expected, "some slight additional fiming was sought." The
Federal funds rate advanced from about around $33 / 4$ percent following the March meeting to about $41 / 4$ percent in the first part of April and remained there until the end of April. "Subsequently, however, despite largescale, reserve-supplying operations by the System, the Federal funds rate advanced to a range around $41 / 2$ per cent."

\section{May Through August: Moderating the Growth of Monetary Aggregates and the Rise of Long-Term Interest Rates}

Evidence of economic recovery was presented during the meetings of this period, with retail sales and housing starts among the strongest indicators. Unemployment, however, remained around the 6 percent level, and there was little evidence of an abatement of intlationary pressures.

The directives of each meeting during this period called for "moderate" or "more moderate" growth in monetary aggregates. However, except for August, the Committee modified this objective in each directive by stating that "developments in capital markets" should be taken into account. This modifying clause might be interpreted as meaning to minimize upward pressures on long-term rates as firmer money market conditions were sought in order to moderate growth of aggregates.

\section{Mov 11 Meeting}

Preliminary Commerce Department figures indicated that real GNP had increased at a 6.5 percent annual rate in the first quarter, after declining at a 3.9 percent rate in the fourth quarter of 1970 . More moderate growth in real GNP was expected in the second quarter.

The deficits in the balance of payments were described as "extremely large" for the first quarter. These deficits were attributed to shorterm capital outflows resulting from the differential between interest rates here and abroad as well as speculation concerning changes in exchange rates. Heavy llows of dollars into Enropean currencies, such as the German mark, were reported in the first few days of April, but had subsided during the next three weeks. In early May several countries, including Germany, Switzerland, the Netherlands, Belginm, and Austria, suspended sales of their currencies for dollars; the German mark and Dutch guilder were floated; and the Swiss franc and Austrian schilling were revalied upward.

Short- and long-term interest rates rose sharply following the April meeting. Growth of the money stock was revised upward $\mathrm{for}_{\mathrm{H}}$ March, bringing $\mathrm{M}_{\mathrm{I}}$ to a 9 percent annual rate in the first quarter. Assuming money market conditions similar to those prevailing during most of April, analysis indicated $\mathbf{M}_{1}$ would increase at about a 9 percent annual. rate in the second quarter. Fven with somewhat firmer money market conditions, $\mathrm{Mi}_{1}$ was expected to grow at about an 8.5 percent rate in the second quarter.

Members of the Committee expressed concern about both rapid growth in monetary aggregates as well as 


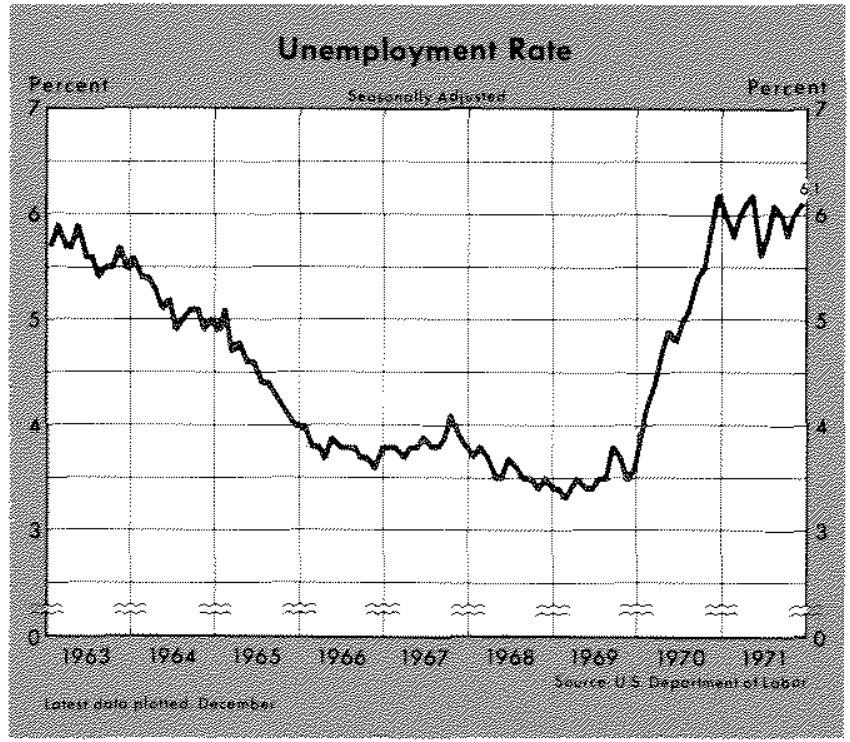

the marked increases in long-tem interest rates. Because of these concerns, the Committee decided neither to revert to the money market conditions which prevailed in April, nor to seek a sharp frming in money market conditions considered necessary to attain a sharp reduction in the growth of aggregates in the second quarter. Initially, the Desk was instructed to maintain prevailing money market conditions in view of even-keel considerations. Thereafter, if significant deviations from the expected paths for the aggregates occurred, money market conditions were to be firmed, but in a cautious manner "with a view to avoiding undue reactions in capital markets." Becanse of uncertainties prevailing in domestic financial and foreign exchange markets, the Acconnt Manager was given more than usual discretion in carrying ont open market transactions.

\section{June 8 and 29 Meetings}

Short-term interest rates continued to increase during May and June, a trend begun in March. Yields on new issue corporate bonds were, on average, about the same in late fune as in early May, while yields on municipal bonds were somewhat higher.

At the early June meeting, it was reported that the money stock, as well as other aggregates, increased in May at substantialy more rapid rates than had been expected at the May meeting. At the late June meeting, preliminary data indicated money was growing rapidly in June, but less rapid than in May. Thus in view of this rapid growth, open market operations were directed towards "somewhat firmer conditions." The Federal funds rate advanced from about $4 \frac{1 / 2}{2}$ percent at the time of the May meeting to abont $5 \frac{1}{8}$ percent at the time of the late June meeting.

At the early fune meeting projections indicated that money would increase at about a 12 percent annual rate in the second quarter, and around 10 or 11 percent in the third quarter, assmming unchanged money market conditions. With somewhat fimer conditions, little change was expected in the second quarter growth rate of money, and a reduction of only about one percent was expected in the third quarter projections. Projections for the growth of money at the late June meeting were similar to those of the early June meeting.

At both of these meetings, members continued to express concen about the rapid growth of aggregates and the rise in interest rates. With regard to monetary aggregates, at the early June meeting the Committee stated its desire to seek "somewhat slower growth over coning months than appeared likely to eventuate if prevailing money market conditions were maintained." The directive of the late June meeting also called for more moderate growth in monetary aggregates. With regard to interest rates the Committee stated at both meetings that a sharp firming of money market conditions should be avoided, so as to minimize upward pressures on long-term interest rates.

\section{Whe 27 Meeting}

Prelininaty Commerce Department estimates indicated that real GNP increased in the second quarter at about half the rate of the first quater. Projections by the staff indicated that real GNP would slow somewhat in the thind quater, but would accelerate in the fourth quarter. Wholesale industrial and consumer prices increased "substantially" in June. It was noted that these price measures had risen at a faster late in the second quarter than earlier in 1971.

The U.S. balance-olmayments deficit for the second quarter was described as "extraordinarily large." This deficit reflected partly the capital outhlows, which resulted more from expectations of a further realignment of currencies and less from interest differentials than in the first quarter, and party a deficit in the trade balance compared with a surplus in the previous guarter. Renewed tensions in foreign exchange markets were also noted in fuly.

Shor-tem interest rates generally rose after the June 29 meeting, while long-term rates changed little on balance after rising in the second quarter. The money stock rose at an 11.5 percent rate in the second quarter, compared with a 9 percent rate in the first quarter. Growth of other monetary aggregates ( $M$. and the bank credit proxy) were noted to have decelerated in the second iplatter.

Analysis presented at the July meeting indicated money would expand at about a 9 percent annual rate in the third quarter and at a much slower rate in the fourth quarter. The Committee agreed more moderate growth of aggregates remained the appropriate objective. However, evenkee considerations were noted as a constaint on open market operations until the next meeting. Also, as in several previous meetings, developmerts in capital markets were to be taken into account. With these short-tem objectives, the Account Manager was again given more that usual discretion in conducting open market operations. 


\section{Augus 24 Weeting}

The President's New Economic Program was announced on August 15, leading to a tentative reappraisal of the economic outlook by the staff. Expectations of a faster growth in real GNP in the rest of 1971 were enhanced when the President announced the new program. The rate of advance of prices was expected to slow, thus reducing somewhat the current-dollar GNP for the remainder of the year. The balance-of-payments deficit was noted to be increasing sharply after mid-year, and was described as "massive" in the first half of August.

Analysis presented at this meeting indicated money growth" would moderate somewhat in August and September and would slow substantially further in the fourth quarter," assuming prevailing money market conditions were maintained. It tioted that becatuse of the new program, projections for growth of aggregates were subject to sizable errors. The Committee decided in view of the difficulties in assessing the impact of the New Economic Program on economic activity, that a "marked change in the stance of policy would be premature." However, the Committee agreed to seek growth in aggregates "well below" the rates of previous months.

\section{September-December: Cautious Move Toward Restoring Money Growth}

In the remainder of 1971 there was a reversal of trends for interest rates and monetary aggregates. Interest rates fell considerably from mid-August 1971 to midJanuary 1972, while the money stock exhibited almost no growth. During this period the Committee desired to have moderate growth in monetary aggregates, but also desired that the easing of money market conditions necessary to achieve this growth be made in a cautious manner. Later in this period, as the substantial reversal in the growth of the aggregates became more apparent, somewhat more emphasis was placed on achieving renewed moderate growth in aggregates.

\section{September 21 and Ochober 19 Meethgs}

At the September meeting the outlook for real GNP was for a "significantly slower" rate of increase in the third quarter than the estimated 4.8 percent rate in the second quarter. Projections for the fourth quarter indicated growth of real GNP would accelerate and price increases would moderate, partly in response to the New Economic Program.

Staff projections reported at the October meeting were optimistic for the first half of 1972 . Real GNP was expected to grow at, or slightly below, the expected fourth quarter rate. This projection was based on an expected growth of consumer spending and business capital outlays. Projections of real GNP for both the fourth quarter of 1971 and the first half of 1972 were "appreciably faster" than those before the announcement of the New Economic Program.

Short- and long-term interest rates fell immediately following the President's announcement. The downward trend in interest rates, in general, continued through the October 19 meeting. At these meetings it was noted that both $\mathrm{M}_{1}$ and $\mathrm{M}_{2}$ had grown at slower rates in August and September than had been anticipated.

Analysis presented at the September meeting indicated that $\mathrm{M}_{1}$ and $\mathrm{M}_{2}$ would grow in the third quarter at rates well below those of the second quarter. If prevailing money market conditions were maintained, money growth was expected to "slow further in the fourth quarter." At the October meeting, analysis suggested that money would increase in the fourth quarter at about the same rate as the third, and that money growh was likely to accelerate in the first quarter of 1972 .

Directives issued at these two meetings called for "moderate growth in monetary and credit aggregates." The September meeting also contained a modifying clause specifying that developments in the capital market should be taken into account. Although the Committee recognized the need for easing money market conditions in order to achieve this moderate growth of aggregates, the Committee at both meetings wanted to avoid an "aggressive" or a "marked" easing in order to achieve moderate growth of money in the near-term.

One reason given for avoiding an aggressive easing of money market conditions was "to minimize the risk of rekindling inflationary expectations." A second reason given was that in view of the rapid growth of money in the first seven months of the year, "a marked easing designed to stimulate faster growth in the near term would not be warranted." A gradual easing of money market conditions was undertaken by the Desk following the September and October meetings.

\section{November 16 Meeting}

Price indexes showed a marked improvement for September and October, reflecting the price-wage freeze. Staff projections of real GNP growth for the fourth quarter of 1971 and the first half of 1972 were reduced slightly from the projections presented at the previous meeting. Following the October meeting, market interest rates continued to decline

Money declined slightly in September and October. Growth of $\mathrm{M}_{1}$ was anticipated to resume in December and accelerate in the first quarter of 1972 , assuming money market conditions were maintained similar to or somewhat easier than those prevailing. It was expected that $\mathrm{M}_{2}$ would grow somewhat faster in the fourth quarter than the 4.5 percent rate in the third quarter.

The uncertainty surrounding the transition from Phase I to Phase II of the President's New Economic Program and the international situation was recognized by the Committee as adversely affecting consumer confidence. Some members felt that persistence of weak performance in the monetary aggregates might add to this uncertainty. Some members continued, however, to warn against "unduly aggressive action to stimulate monetary expansion."

The Committee directed that "somewhat greater growth" of monetary aggregates should be attained over the months ahead. The Committee recognized that "appreciably easier money market conditions" might be necessary in order to achieve this growth. 


\section{December 14 Meethy}

Commerce Department estimates of real GNP growth were revised upward to 4 percent for the third quarter. Growth of real GNP appeared to be somewhat faster in the fourth quarter as well. The rates of increase in prices and wages were sharply lower during the "freeze" period.

Money changed little in November and, on balance, no growth in money occurred from August to November. Some short- and long-term interest rates rose slightly following the November meeting, but most rates began to decline again before the December meeting. Following the November meeting, the Federal funds rate fell from about $43 / 4$ percent to about $43 \%$ percent at the time of the December meeting.
Analysis indicated that easing of money market conditions would likely be required to achieve moderate growth of $M_{1}$ in December and January. The weakness of $\mathrm{M}_{1}$ and total member bank reserves over the previous four months was of "considerable concem" to some of the Committee. Some members urged "more aggressive actions" be taken, while others desired a "more cautious and gradual" approach. The Committee agreed, however,

... to promote the degree of ease in bank reserve and money market conditions essential to greater growth in monetary aggregates over the months ahead.

This article is avaliable as Reprint No. 76

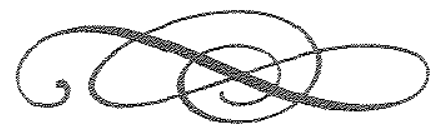

